1

f. The

Kol H

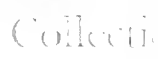

A Memorial to the Founder of the

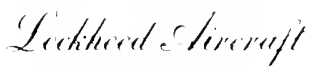
ireperentien

Busines Adminitation Litnars

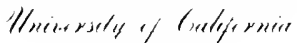
Low Ingeles 


\section{OBSERVATIONS} O N T II E

I M P O R T A N G F O F T II E

\section{AMERICAN REVOLUTION,}

\section{$A \mathrm{~N} D$}

The MEANs of making it a BENEEIT to the Wont

TO WHICH IS ANDED,

A Letter from M. Turcot, late Comptroller. General of the Finarces of France:

W:TH

An APPENDIx, containing a Trannation of the WILl of M. Forturé RICARD, lately publinhol in France.

\section{By RICHARD PRICE, D.D.I.L.D.}

And FELLOW of the ROYAL SOCIETY of LO:DON, and of the ACADEMr of ARTs and ScIElices in NawENGLAND.

\section{O N D O IT:}

Printed for T. Cadell, in the Stravd. M.DCC.LXXXY. 

TO

The Free and United States of

\section{A M E R I C A,}

THE FOLLOWENG OBSERVATIONS

ARE HUMBIY OFFERED,

AS

A LAST TESTIMONY

$O F$

THE GOOD - WILL

ox

THE AUTHOR. 



\section{$E R \quad R A T$.}

P. 148. For tranfacting in bufines, rad tranfacting bus
inefs.

P. 153. In lines 5 th and 8 th, for the numbers 131,501 , 139,560 , and 143,890 , read $13,150,13,956$, and 14,389 . 



\section{$\left[\begin{array}{ll}\mathrm{v} & ]\end{array}\right.$}

\section{$\begin{array}{llllllllllll}C & O & N & T & E & N & T & S .\end{array}$}

F the Importance of the Revolution which has eftabiifhed the Independence of the United States of America. - p. I Of the means of promoting human Improvement and Happinefs in the United States.-And firft, of Public Debts.

Of $P_{E A C E}$, and the Means of perpetuating it. $\quad 14$ Of Liberty.

Of Liberty of Difcufion. 22

Of Liberty of Confcience, and Civil Eftablinments of Religion.

34

Of Education. 50

Of the Dangers to which the American States are expofed.

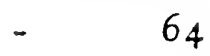

Of Dezts and Internal Wars. - $\quad 66$ Of an unequal Diftribution of Property. 68 Of Trade, Banks, and Public Credit. $\quad 74$ Of OAths. $-\quad 8 \mathrm{r}$ Of the Negro Trade and Slavery. $\quad-\quad 83$ Conclufion. - $\quad-\quad$ - 84 Letter from M. Turgot. - $\quad$ - 89 Tranfation of M. Turgot's Letter. 107 Appendix, containing a Trandation of the Will of M. Fortuné Ricard. 129 Tables.

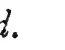

150 

[ vii ]

\section{A D V E R T I E MENT.}

TAVING reafon to bope I frould be at11 tended to in the American States, and thinking I faw an opening there favourable to the improvement and beft interefts of mankind, $I$ bave been induced to convey thither the fentiments and advice contained in the following Obfervations. They were, therefore, originally intended only for America. The danger of $a$ Jpurious edition bas now obliged me to publif $f_{3}$ them in my oron country.

I frould be inexcufable did I not take this opportunity to exprefs my gratitude to a diflinguifhed writer (the Count de Mirabeau) for bis tranflation of thefe Obfervations into French, and for the fupport and kind civility with wobich it bas been accompanied.

Mr. Turgot's letter formed a part of this tract when it was conveyed to America. I bas: nowe given a tranglation of it. 


\section{[ viii ]}

I think it neceffary to add that I bave expreffed myfelf in fome reppects too frongly in the conclufion of the following Obfervations. By accounts from peifons the beft informed, I bave lately, been affured that no fuch diffentions exift among the American States as bave been given

' out in this country; that the new governments are in general well fettled, and the people bappy under them; and that, in particular, a convition is becoming univerfal of the necefity of giving more frength to that power which forms and which is to conduct and maintain their union.

March, $17^{8} 5$ 


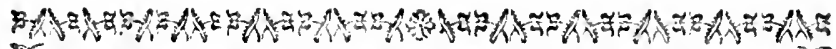

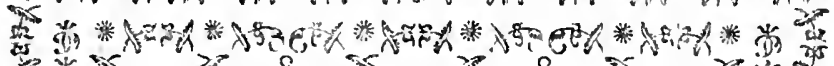

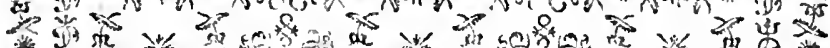

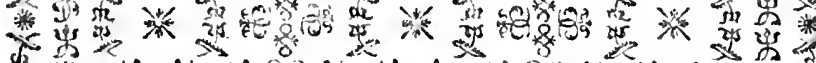

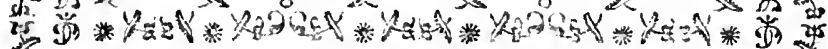

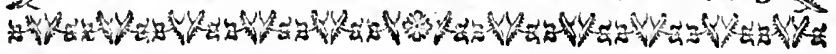

\section{O BSERVATIONS, \&c.}

Of the Importance of the Revolution which bas eftablifhed the Independence of the United States.

1. AVING, from pure convidtion, taken 每 a warm part in favour of the Britifs colonies (now the United States of America) during the late war; and been expofed, in confequence of this, to mucb abule and fome danger; it murt be fuppofed that I have been waiting for the iffue with anxiety - I am thankful that my anxiety is removed; and that I bave been fpared to be a witnefs to that very iffue of the war which has been all along the object of my withes. With heart-felt fatisfacion, I fee the revolution in favour of univerfal liberty which has taken place in America; - - revolution which opens a new profpect in bu- 


\section{$\left[\begin{array}{lll}2 & ]\end{array}\right.$}

man affairs, and begins a new æra in the hiftory of mankind; a revolution by which Britons themfelves will be the greateft ' gainers, if wife enough to improve properly the check that has been given to the defpotifm of their minifters, and to catch the flame of virtuous liberty which has faved their American brethren.

The late war, in its commencement and progrefs, did great rood by diffeminating juft fentiments of the rights of mankind, and the nature of legitimate government; by exciting a fpirit of refifance to tyranny which has emancipated one European country, and is likely to emancipate others; and by occaficning the eftablinment in America of forms of government more equitable and

- more liberal than any that the world has yet known. But, in its termination, the war has done ftill, greater good by preferving the new governmenis from that defirucion in which they mut have been involved, had Britain conquered; by providing, in a fequeftered continent poffeffed of many fingular advantages, a place of refuge - for oppeft men in every region of the world; and by laying the foundation there 


\section{[ 3 ]}

of an empire which may be the feat of liberty, fcience and virtue, and from whence there is reafon to hope thefe facred bleffings will fpread, till they become univerfal, and the time arrives when kings and priefts thall, have no more power to opprefs, and that ignominious Mavery which has hitherto debafed the world is exterminated. I therefore, think I fee the hand of Providence in the late war working for the general good.

Reafon, as well as tradition and revelation, lead us to expect that a more improved and happy ftate of human affairs will take place before the confummation of all things. The world has hitherto been gradually improving. Light and knowledge have, been gaining ground, and human life at prefent compared with what it once was, is much the fame that a youth approaching to manhood is compared with an infant.

Such are the natures of things that this progrefs muft continue. During particular intervals it may be interrupted, but it cannot be deftroy'd. Every prefent advance prepares the way for farther advances; and a fingle experiment or difcovery may fomeB 2 times 


$$
\text { [ } 4 \text { ] }
$$

times give rife to fo many more as fuddenly to raife the fpecies higher, and to refemble the effects of opening a now fenfe, or of the fall of a fpark on a train that fprings a mine. For this reafon, mankind may at laft arrive at degrees of improvement which we cannot now even fufpect to be poffible. A idark age may follow an enlightened age; but, in this cafe, the light, aftcr being fmothered for a time, will break out again with a brighter luftre. The prefent age of increafed light, confidered as fucceeding the ages of Greece and Rome and an intermediate period of thick darknefs, furnithes a proof of the truth of this obfervation. There are certain kinds of improvement which, when once made, cannot be entirely loft. During the dark ages, the improvements made in the ages that preceded them remained fo far as to be recovered immediately at the refurrection of letters, and to produce afterwards that more rapid progicks in improvement which has diftinguifhed moders times.

There an farcely be a more pleafing and encouraging object of reflection than this. An accidental obfervation of the effects of gravity in a garden has been the means 


\section{[ 5 [ ]}

of difcovering the laws that govern the folar fyftem*, and of enabling us to look down with pity on the ignorance of the moft enlightened times among the antients. What new dignity has been given to man, and what additions have been made to his powers, by the invention of optical glafies, printing, gun-powder, \&c. and by the late difcoveries in navigation, inathematics, natural philofopby, \&c.? †

* This refers to an account given of Sir Íaac Newton in the Preface to Dr. Pemberton's View of his Philofophy.

+ Who could have thought, in the firft ages of the world, that mankind would acquire the power of deter-1 mining the diftances and magnitudes of the fun and planets ? - Who, cven at the beginning of this century, would have thought, that, in a few years, mankind would arquire the power of fubjecting to their wills the dreadful force of lightening, and of flying in aeroftatic machines? - The laft of thefe powers, though fo long undifcovered, is only an eafy application of a power always known.-Many fimilar difcoveries may remain to be made, which will give new dircctions of the greate? confequence to human affairs; and it may not be too extravagant to expect that (hould civil governments throw no obfiacles in the way) the progrefs of improvement will not ceafe till it has excluded from the earth moft of its worft cvils, and reltored that Paradifaical ftate which, according to the Moraic Hiftory, preceded the prefent ftate. 


\section{[ 6 r $]$}

But among the events in modern times tending to the elevation of mankind, there are none probably of fo much confequence as the recent one which occafions thefe obfervations. Perhaps, I do not go too far when I fay that, next to the introduction of Chriftianity among mankind, the American revolution may prove the moft important fep in the progrefive courfe of human improvement. It is an event which may produce a general diffufion of the principles of humanity, and become the means of fetting free mankind from the - Mackles of fuperftition and tyranny, by leading them to fee and know " that nothing " is fundamental but impartial enquiry, an " honeft mind, and virtuous practice" that fate policy ought not to be applied " to the fupport of fpeculative opinions " and formularies of faith." - " That the " members of a civil community are * con"federates, not fubjects; and their rulers, "firvants, not mafters. - And that all " legitimate government confifts in the do" minion of equal laws made with com"mon confent; that is, in the dominion

* There are the words of Montescuiev. 


\section{[ 7 ]}

" of men over themfelves; and not in the " dominion of communities over commu" nities, or of any men over other men."

Happy will the world be when thefe truths hall be every where acknowledged and practifed upon. Religious bigotry, that cruel demon, will be then laid afleep. Slavifh governments and havifh Hierarchies will then fink; and the old prophecies be verified, "that the laft univerfal empire " upon earth thall be the empire of reafon " and virtue, under which the gofpel of " peace (better underfood) Soall bave free "courfe and be glorified, many will run to " and fro and knowledge be increafed, the " wolf dwell with the lamb and the leopard "with the kid, and nation no more lift up " a fword againft nation."

It is a conviction I cannot refin, that the independence of the Englifs colonies in America is one of the fleps ordained by, Providence to introduce thefe times; and I can fcarcely be deceived in this conviction, if the United States fhould efcape fome dangers which threaten them, and will take proper care to throw themfelves open to future improvements, and to make the mont of the advantages of their prefent 


$$
\text { [ } 8 \text { ] }
$$

fituation. Should this happen, it will be true of them as it was of the people of the Jews, that in them all the families of the eartb joall be bleffed. It is farcely poflible they hould think too highly of their own confequence. Perhaps, there never exifted a people on whole wifdom and virtue more depended; or to whom a ftation of more importance in the plan of Providence has been affigned. They have begun nobly. They have fought with fuccels for themfelves and for the world; and, in the midft of invafion and carnage, eftablifhed forms , of government favourable in the highef degree to the rights of mankind. - But they have much more to do; more indeed than it is poffible properly to reprefent. In this addrefs, my defign is only to take notice of a few great points which feem particularly to require their attention, in order to render them permanently happy in themelves and ufeful to mankind. On thefe points, I thall deliver my fentiments with ficedom, confcious I mean well; but, it the fame time, with real diffidence, confcious of my own liablenefs to error. 


\section{$\left[\begin{array}{ll}9 & 1\end{array}\right.$}

Of the Means of promoting buman Improvement and Happiness in the United States. - And firfi, of Public Debts.

$I^{\mathrm{T}}$ fcems evident, that what firt requires 1 the attention of the United States is the redemption of their debts, and making compenfation to that army which has carried them through the war. They have an infant credit to cherifh and rear, which, if this is not done, muft perinh, and with it their character and honour fot ever. Nor is it conceivable they fhould meet with any great difficulties in doing this. They have a vaft refource peculiar to themfelves, in a continent of unlocated lands poffefing every advantage of foil and climate. The fettlement of thefe lands will be rapid, the confequence of which mutt be a tapid increafe of their value. By difpofing of, them to the army and to emigrants, the greatent part of the debts of the United States may probably be funk immediatcly. But had they no fuch refource, they are very capable of bearing taxes fufficient for the purpofe of a gradual redemption. Sup- 


\section{[ 10 ]}

poling their debts to amount to nine millions Rerling, carrying interef at $5 \frac{x}{2}$ per cent. taxes producing a revenue of a million per ann. would pay the interen, and at the fame time leave a furplus of balf a million per ann. for a finking fund, which would difcharge the principal in thirteen years. A furplus of a quarier of a million would do the fame in $20 \frac{1}{2}$ years. After difcharging the principal, the appropriated revenue being no longrer wanted, might be abolimed, and the States eares of the burthen of it. But it would be imprudent to abolin it entirely. 100,000l. per anm. referved, and faithfully laid out in clearing unlocated lands and other improvements, would in a hort time increafe to a treafure (or continental patrimony) which would defray the whole expenditure of the union, and keep the States free from debts and taxes for ever\%. Such a referve would (fup-

* The lands, forefts, impofts, \&x. Exc. which once formed the patrimony of the crown in England, bore moft of the expences of government. It is well for this kingdom that the extravagance of the crown has been the means of alienating this patrimony, for the confequence has been making the crown dependent on the perple. But in Americal fuch a patrimony would be continental property, capable of being applied only to public purpofes, in the way which the public for its delegates) would approve.

poling 


\section{[ I I ]}

pofing it improved fo as to produce a profit of 5 fer cent.) increafe to a capital of three millions in 19 years, 30 millions in 57 years, 100 millions in 81 yerrs, and 26 I millions in 100 years. But fuppofing it capable of being improved fo as to produce a profit of 10 per cent. it would increafe to five millions in 19 years, 100 millions in 49 years, and 10,000 millions in 97 years.

It is wonderful that no ftate has yet thought of taking this method to make itfelf great and rich. The fmalleft appro- 1 priation in a finking fund, never diverted, operates in cancelling debts, juft as money increafes at compound intereft; and is, therefore, omipotent $*$ But, if diverted, it lofes all its power. BRITAIN affords a Atriking proof of this. Its finking fund (once the hope of the kingdom) has, by

* One penny put out at our Saviour's birth to 5 por cent. compound intereft would, before this time, have increated to a greater fum than would be contained in 1 TwO HUNDRED MiLli JNS of Earths all folid gold. Bur, if put out to fimple intereft, it would have amounted to no more than feven fillings and fix-pince. All governments which alienate funds deftined for teimburfements, chufe to improve money in the luf rather than the firft of thefe ways. 


\section{[ $\left.\begin{array}{lll}1 & 2\end{array}\right]$}

the practice of alienating it, been rendered impotent and ufelefs. Had it been inviolably applied to the purpore for which it was intended, there would, in the year I775, have been a furplus in the revenue of more than five millions per ann. But inftead of this, we were then encumbered with a debt of 137 millions, carrying an intereft of near $4 \frac{1}{2}$ millions, and leaving no furplus of any confequence. This debt - has been fince increafed to * 280 millions, carrying an intereft (including expences of management) of nine millions and a half.A monftrous bubble; - - and if no very ftrong meafures are foon taken to reduce it within the limits of fafety, it muft produce a dreadful convulfion. Let the United States take warning-Their debts at prefent are moderate. A Sinking fund, guarded $\uparrow$ againft mifapplication, may foon extinguifh them, and prove a refource in all events of the greateft importance.

* See the Poffcrift to a pamphlet, entitled, The State of the Finances of the Kingdom, at figning the Preliminary Articles of Peace in January 1783 , printed for Mr. Cadell.

+ When not thus guarded, public funds become the worft cvils, by giving to the rulers of ftates a command of revenue for the purpoles of corruption.

I muft 


\section{[ I 3 ]}

I muft not, however, forget that there is ONE of their debts on which no fnking fund can have any effect; and which it is impoffible for them to difcharge:

A debt, greater, perhaps, than has been ever due from any country; and which will be deeply felt by their lateft porterity. - But it is a debt of GRATITUDE onlyOf GRATITUDE to that General, who has ' been raifed up by Providence to make them free and independent, and whofe name muft thine among the firtt in the future annals of the benefactors of mankind.

The meafure now propofed may preferve America for ever from too great an accumulation of debts; and, confequently, of taxes-an evil which is likely to be the ruin not only of Britain, but of other European States. - But there are meafures of yet greater confequence, which I win ardently to recommend and inculcate.

For the fake of mankind, I with to fee every meafure adopted that can have a tendency to preferve PEACE in America; and to make it an open and fair ftage for difcurfion, and the feat of PERFECT LIBERTY. 


\section{[ 14 ] \\ Of PEACF,}

And the Means of perpetuating it.

CIVIL Government is an expedient for collecting the wifdom and force of a community or confederacy, in order to preferve its peace and liberty againftevery hoftile invalion, whether from within or from witbout. - In the latter of thefe refpects, the United States are happily fecured; but they are far from being equally happy in the former refpect. Having now, in confequence of their fuccefsful refiftance of the invafion of Britain, united to their remotenefs from Europe, no external enemy I to fear, they are in danger of fighting with one another. - This is their greatef danger; and providing fecurities againft it is their bardeft work. Should they fail in this, America may fome time or other be turned into a fcene of blood; and infead of being the hope and refuge of the world, may become a terror to it.

When a difpute arifes among individuals in a Siate, an appeal is made to a court of 


\section{$\left[\begin{array}{lll}2 & 15\end{array}\right]$}

law; that is, to the wifdom and juftice of the State. The court decides. The lofing party acquiefces; or, if he does not, the power of the State forces him to fubmiffion; and thus the effects of contention are fuppreft, and peace is maintained.-In a way fimilar to this, peace may be maintained between any number of confederated States; and I can almoft imagine, that it is not impoffible but that by fuch means univerfal peace may be produced, and all war excluded from the world. - Why may we not hope to fee this begun in America? - The articles of confederation make confiderable advances towards it. When a difpute arifes between any of the States, they order an appeal to Congrefs, , - an enquiry by Congress, - a hearing, and a decifion.-But here they fop.-What is molt of all neceffary is omitted. No provifion is made for enforcing the deci-' fions of Congrefs; and this renders them inefficient and futile. I am by no means qualified to point out the beft method of removing this defect. Much muft be given up for this purpore, nor is it eafy to give up too much. Without all doubt the 


$$
\text { [ } 16]
$$

' powers of Congrefs munt be enlarged. In particular, a power muft be given it to collect, on certain emergencies, the force of the confederacy, and to employ it in carrying its decifions into execution. A State againft which a decifion is made, will yield of courfe when it knows that fuch a force exifts, and that it allows no hope from refiftance.

By this force I do not mean a STANDING ARMY. God forbid, that ftanding armies fhould ever find an efablifhment in America. They are every where the grand ' fupports of arbitrary power, and the chief caufes of the depreffion of mankind. No wife people will truft their defence out of their own hands, or confent to hold their rights at the mercy of armed flaves. Free States ought to be bodies of armed citizens, well regulated, and well difciplined, and always ready to turn out, when properly called upon, to execute the laws, to quell riots, and to keep the peace. Such, if I am rightly informed, are the citizens of America. Why then may not Congress 1 be furnithed with a power of calling out from the confederated States, quotas of militio fufficient to force at once the com-

pliance 


\section{$\left[\begin{array}{lll}17 & \end{array}\right]$}

pliance of any State which may thew an inclination to break the union by refinting its decifions?

I am very fenfible that it will be difficult to guard fuch a power againf abufe; and, perhaps, better means of anfwering this end are difcoverable. In human affairs, however, the choice generally offered us is " of two evils to take the leaft." We chufe the reftraint of civil government, becaufe a lefs evil than anarchy; and, in like manner, in the prefent inftance, the danger of the abufe of power, and of its being employed fometimes to enforce wrong decifions, mutt be fubmitted to, becaufe a lefs evil than the mifery of intertine wars. Much, however, may be done to leffen this danger. Such regulations as thofe in the ninth of the articles of confederation will, in a great meafure, prevent hafty and partial decifions. The rotation eftablifhed by the fifth article will prevent that corruption of character which feldom fails to be produced by the long poffefion of power; and the right referved to every State of recalling its Delegates I when diffatisfied with them, will keep them conftantly refponfible and cautious. 


\section{[}

The obfervations now made muft be extended to money tranfactions. Congrefs mut be trutted with a power of procuring I fupplies for defraying the expences of the confederation; of contracing debts, and providing funds for difcharging them: and this power munt not be capable of bcing defeated by the oppofition of any minority in the States.

In hort, the credit of the United States, their ftrength, their refpectablenefs abroad, their liberty at home, and even their exiffence, depend on the prefervation of a firm political union; and fuch an union cannot be preferved, without giving all poffible weight and energy to the authority of that delegation which conftitutes the union.

Would it not be proper to take periodical furveys of the different ftates, their numbers of both fexes in every ftage of life, their condition, occupations, property, \&c.?-Would not fuch furveys, in conjundtion with accurate regifters of births, marriages and deaths at all ages, afford much important inftruction by thew- 


$$
\text { [ I9] }
$$

ing what laws govern human mortality, and what fituations, employments, and civil inftitutions, are moft favourable to the health and happinefs of mankind?Would they not keep conftantly in view the progrefs of population in the ftates, and the increafe or decline of their refources? But more efpecially, are they not the only means of procuring the neceffary information for determining accurately and equitably the proportions of men and money to be contributed by each ftate for fupporting and frengthening the confederation? 


\section{[ 20 ]}

\section{Of LIBERTY.}

$T^{H E}$ next point I would infift on, as 1 an object of fupreme importance, is the eftablifhment of fuch a fyftem of perfect liberty, religious as well as civil, in America, as thall render it a country where truth and reafon thall have fair play, and the human powers find full fcope for exerting themfelves, and for hewing how far they can carry human improvement.

The faculties of man have hitherto, in all countries, been more or lefs cramped by the interference of civil authority in matters of fpeculation, by tyrannical laws againft herefy and fchifm, and by flavinh hierarchies and religious eftablihments. It is above all things defirable that no fuch fetters on reafon fhould be admitted into America. I obferve, with inexpreffible fatisfaction, that at prefent they have no exiftence there. In this refpect the governments of the United States are liberal to a degree that is unparalleled. They have the diffinguifhed honour of being the firft 


\section{[ 2 2 $]$}

ftates under heaven in which forms of go- 1 vernment have been eftablifhed favourable to univerfal liberty. They have been thus diftinguihed in their infancy. What then will they be in a more advanced ftate; when time and experience, and the concurring affiftance of the wife and virtuous in every part of the earth, hall have introduced into the new governments, corrections and amendments which will render them ftill more friendly to liberty, and more the means of promoting human happinefs and dignity? - May we not fee there the dawning of brighter days on earth, and a new creation rifing. But I muft check myfelf. I am in danger of being carried too far by the ardor of my hopes.

The liberty I mean inciudes in it liberty of conduct in all civil matters-liberty of difcuffion in all ppeculative matters-and liberty of confcience in all religious matters. - And it is then perfect, when under no reftraint except when ufed to injure any one in his perfon, property, or good name; that is, except when ufed to deftroy itfelf. 


\section{[ $\begin{array}{ll}22 & \text { ] }\end{array}$}

In liberty of difcuftion, I include the liberty of examining all public meafures, and the conduct of all public men; and of writing and publinhing on all fpeculative and doctrinal points.

\section{Of LIBERTY of DYSCUSSION.}

$T$ is a common opinion, that there are 2 fome doctrines fo facred, and others of fo bad a tendency, that no public difcuftion of them ought to be allowed. Were this a right opinion, all the perfecution that has been ever practifed would be juftified. For, if it is a part of the duty of civil magiftrates to prevent the difcufion of fuch doctrines, they muft, in doing this, act on their own judgments of the nature and tendency of doctrines; and, confequently, they muit have a right to prevent the difcuffion of all docinines which they think to be too facred for difcupion or too dangerous in their rendency; and this right they mut exercife in the only way in which civil power is caprible of exercifing it, "by inflicting " penalties 


\section{$\left[\begin{array}{lll}2 & 3\end{array}\right]$}

"penalties on all who oppofe facred doc" trines, or who maintain pernicious opi" nions." - In Mabometan countries, therefore, civil magiftrates have a right to filence and punifh all who oppore the divine miffion of Mabomet, a doctrine there teckoned of the mont facred nature. The like is true of the doctrines of tranfubitantiation, worhip of the Virgin Mary, \&cc. in Popi/b countries; and of the doctrines of the Trinity, fatisfaction, \&cc. in Proteftant countries. - In England itfelf, this principle has been acted upon, and produced the laws which fubject to fevere penalties all who write or fpeak againft the Supreme Divinity of Chrift, the Book of Common Prayer, and the Church Articles of Faith. All fuch laws are right, if the opinion I have mentioned is right. But in reality, civil power has nothing to do with any fuch matters; and civil governors go miferably out of their proper province, whenever they take upon them the care of truth, or the fupport of any doctrinal points. They are not judges of truth; and if they pretend to decide about it, they will decide wrong. This all the countries under heaven think of the application 


\section{$\left[\begin{array}{lll}24 & \end{array}\right]$}

- plication of civil power to doetrinal points in every country but their own. It is, indeed, fuperfition, idolatry, and nonfenfe, that civil power at prefent fupports almoft every where, under the idea of fupporting facred truth, and oppofing dangetous error. Would not, therefore, its perfect neutrality be the greateft bleffing? Would not the intereft of truth gain unfpeakably, were all the rulers of States to aim at nothing but keeping the peace; or did they confider themlelves as bound to take care, not of the future, but the prefent intereft of men;not of their fouls and their faith, but of their perfons and property; - not of any ecclefiafical, but fecular matters only?

All the experience of paft time proves that the confequence of allowing civil power to judge of the nature and tendency of doctrines, mut be making it a hindrance to the progrefs of truth, and an enemy to the improvement of the world.

Anavagoras was tried and condemned in Greece for teaching that the fun and fars were not Deities, but maffes of corruptible matter. Acculations of a like kind contributed to the death of Socrates. The threats of bigots and the fear of perfecu-

tion, 


\section{$\left[\begin{array}{lll}2 & 5\end{array}\right]$}

tion, prevented Copernicus from publih. ing, during his whole life-time, his difcovery of the true fyftem of the world. $G a-$ lileo was obliged to renounce the doctrine of the motion of the earth, and fuffered a year's imprifonment for having afierted it. And fo lately as the year 1742 , the beft commentary on the firft production of human genius (Newton's Principia) was not allowed to be printed at Rome, becaufe it afferted this doctrine; and the learned commentators were obliged to prefix to their work a declaration, that on this point they fubmitted to the decifions of the fupreme Pontiffs. Such bave been, and fuch (while men continue blind and ignorant) will always be the confequences of the in- 4 terpofition of civil governments in matters of fpeculation.

When men affociate for the purpore of civil government, they do it, not to defend truth or to fupport formularies of faith and Speculative opinions; but to defend their civil rights, and to protect one another in the free exercife of their mental and corporeal powers. The interference, therefore, of civil authority in fuch cafes 


\section{$\left[\begin{array}{lll}2 & 26\end{array}\right]$}

is direcity contrary to the end of its inftitution. The way in which it can beft promote the intereft and dignity of mankind, (as far as they can be promoted by the difcovery of truth) is, by encouraging them to fearch for truth whereever they can find it; and by protecting. them in doing this againft the attacks of malevolence and bigotry. Should any attempt be made by contending fects to injure one another, its power will come in properly to cruth the attempt, and to maintain for all fects equal liberty, by punilhing every encroachment upon it. The conduet of a civil magiftrate, on fuch an occafion, hould be that of Gallio the wife Roman proconful, who, on receiving an acculation of the apofte Paul, would not linen to it, but drove from his prefence the accufers who had laid violent hands upon him, after giving them the following ad-

1 monition :-If it were a matter of wrong or wicked lewdine/s, reajon wosuld require that I flould bear with your. But if it be a question of words and names and the law, look you to it. For I wiill be no judge of fuch maters. ACAs xviii. 12. \&xc. Ifow much happier would the world have been, had all maginrates aeted in this manner? Let 


\section{$\left[\begin{array}{lll}2 & 27\end{array}\right]$}

America learn this important leffon, and profit by the experience of paft times. A diffent from efablifed opinions and doctrines has indeed often miferably difturbed fociery, and produced mifchief and bloodhed. But it hould be remembered, that this has been owing to the efululifinment of the points difiented from, and the ufe of civil power to enforce the reception of them. Had civil government done its duty, left all free, and employed itfelf in procuring inftead of reftraining fair difcuffion, all mifchief would have been avoided, and mankind would have been raifed higher than they are in knowledge and improvement.

When Chriftianity, that firft and ben of all the means of human improvement, was firit preached, it was charged with turning the world upfide down. The leaders of Jewifl and Pagan eftablihments were alarmed, and by oppofing the propagation of it, converted a religion of peace and love into an occafion of violence and flaughier; and thus verifed our Lord's prophecy, that he was come not to fend peace, bui a fiword on earth. All this was the effect of the mifapplication

$$
\text { E } 2
$$




\section{$\left[\begin{array}{ll}28 & ]\end{array}\right.$}

of the powers of government. Inftead of creating, they fhould have been employed in preventing fuch mischief, and been active only in cauling the Chriftian caufe to receive a fair hearing, and guarding the propagators of it againft infult.-The like obfervation may be made concerning the firft reformers. - What we all fee would have been right in Pagan and Popifl governments with refpect to Chriftianity and the Reformation; would it not be now right in Chriftian or Proteftant governments, were any attempts made to propagate a new religion, or any doctrines advanced oppofite to thofe now held facred ? Such attempts, if unfupported by reafon and evidence, would foon come to nothing. An imponture cannot fand the teft of fair and open examination. On the contrary, the caufe of truth will certainly be ferved , by it. Mabonetanifm would have funk as foon as it rofe, had no other force than that of evidence been employed to propagate it and it is an unfpeakable recommendation of Cbrifionity, that it made its way till it became the religion of the world in one of its moft enlightened periods, by evidence only, in oppofition to the ftrongeft exer- 


\section{$\left[\begin{array}{ll}29 & {[}\end{array}\right]$}

tions of civil power. There cannot be a more ftriking proof, that notiing but fair difcuffion is neceliary to fupprefs error and to propagate truth. I am grieved, indeed, whenever I find any Chrifians thewing a difpofition to call in the aid of civil power to defend their religion. Nothing can be more difgraceful to it. If it wants fucb aid, it cannot be of God. Its corruption, and debafement took place from the moment that civil power took it under its patronage; and this corruption and debafement increafed, till at laft it was converted into a fyitem of abfurdity and fuper-, ftition more grofs and more barbarous than Paganifm itfelf._-The religion of Chrit difclaims all connexion with the civil eftablithments of the woild. It has fuffered infinitely by their friendfoip, Inftead of filencing its opponents, let them be cncouraged to produce their frongeft arguments againft it. The experience of Britain has lately thewn that this will only caufe it to be better uniciftood and more firmly believed.

I would extend the fe obfervations to all points of faith, however facred they may be 


\section{[ 30 ]}

te deemed. Nothing reafonable can fuffer by difcufion. All doctrines really facred muft be clear and incapable of being oppofed with fuccefs. If civil authority interpofes, it will be to fupport fome mifconception or abufe of them.

That immoral tendency of doctrines which has been urged as a reafon againft allowing the public difcuftion of them, muft be either avowed and direct, or only a confequence with which they are charged. If it is avowed and direct, fuch doctrines certainly will not fpread. The principles rooted in human nature will refift them; and the advocates of them will be foon difgraced. If, on the contrary, it is only a confequence with which a doctrine is charged, it Should be confidered how apt all parties are to charge the doctrines they oppofe with bad tendencies. It is well known, that Calvinits and Arminians, Trinitarians and Socinians, Fatalifts and Free-willers, are continually exclaiming againt one another's opinions as dangerous and licentious. Even Chriftianity itfelf could not, at its firft - introduction, efcape this accufation. The profeffors of it were confidered as Atbeifts, becaufe they oppofed Pagan idolatry; and 


\section{[ $\left.3^{1} \quad\right]$}

their religion was on this account reckoned a deftruetive and pernicious enthufiafm. If, therefore, the rulers of a State are to prohibit the propagation of all doctrines in which they apprehend immoral tendencies, an opening will be made, as I have before obferved, for every fpecies of perfecution. There will be no doctrine, however true or important, the avowal of which will not in fome country or other be fubjected to civil penalties. - Undoubtedly, there are doctrines which have fuch tendencies. But, the tendencies of fpeculative opinions have often very little effect on practice. The Author of nature has planted in the human mind principles and feelings which will operate in oppofition to any theories that may feem to contradiot them. Every fect, whatever may be its tenets, has fome falro , for the neceffity of virtue. The philofophers who hold that matter and motion have no exiftence except in our own ideas, are capable of believing this only in their clofets. The fame is true of the philofophers who hold that nothing exifts but matter and motion; and at the fame time teach, that man has no felf-determining 


\section{[ $\left.\hat{3}^{2}\right]$}

power; that an unalterable fate governs all things and that no one is any thing that he can avoid being, or does any thing that he can avoid doing.- Thefe philofophers when they come out into the world act as other men do. Common fenfe never fails to get the better of their theories; and I know that many of them arc fome of the beft as well as the ableft men in the world, and the warmeft friends to the true interefts of fociety. Though their doctrine may feem to furnifh an apology for ivice, their practice is an exhibition of virtue; and a government which would filence them would greatly injure itfelf.- Only overt acis of injuftice, violence or defamation, come properly under the cognizance of civil power. Were a perfon now to go about London, teaching that " pro" perty is founded in grace," I hould, were $I$ a magiftrate, let him alone while he did nothing but teack, without being under any other apprehenfion than that he would foon find a lodging in Bedlam. But - were he to attempt to carry his doctrine into its confequences by actually fealing, under the pretence of his right as a faint to the property of his neighbours, I fhould think 


\section{[ 33 ]}

think it my duty to lay hold of him as a felon, without regarding the opinion from which he acted.

I am perfuaded, that few or no inconveniencies would arife from fuch a liberty. If magiftrates will do their duty as foon as violence begins, or any overt acts which break the peace are committed, no great harm will arife from their keeping themfelves neutral till then. Let, however, the contrary be fuppofed. Let it be granted that civil authority will in this cafe often be too late in its exertions; the juft inference will be, not that the liberty I plead for ought not to be allowed; but that there will be two evils, between which ' an option muft be made, and the leaft of which munt be preferred.-One is, the evil juft mentioned.-The otker includes in it every evil which can arife from making the rulers of States judges of the tendency of doctrines, fubjecting freedom of enquiry to the controul of their ignorance, and perpetuating darknefs, intolerance and flavery. I need not fay which of thefe evils is the leaft. 


\section{[ 34 ]}

Of Liberty of Conscience, and Civil Establishments of Redigion.

$7 N$ Liberty of Conscience I include I much more than Tuleration. Jefus Chrift has eftablifhed a perfect equality among his followers. His command is, that they thall afume no jurifdiction over one another, and acknowledge no mafter befidcs binnfelf.- - It is, therefore, prefumption in any of them to claim a right to any fuperiority or pre-eminence over their brethren. Such a claim is implied, whenever any of them pretend to tolerate the reft.- - Not only all Chrifianis, but all men of all religions ought to be confidered by a State as equally entitled to its protection as far as they demean themfelves honeftly and peaceably. Toleration can take place only where there is a civil eftablihment of a particuJar mode of religion; that is, where a pre- dominant fect enjoys exclufive advantages, and malses the encouragement of its own mode of fuith and worthip a part of the confitution of the State; but at the fame time 


\section{[ 35 ]}

time thinks fit to SUFFER the exercife of other modes of faith and worhip. Thanks be to God, the new American States are at prefent ftrangers to fuch eftablifhmonts. In this refpect, as well as many others, they have thewn, in framing their conftitutions, a degree of wifdom and liberality which is above all praife.

Civil eftablithments of formularies of faith and worhip are inconfintent with the rights of private judgment-They ingender Arife-They turn religion into a tradeThey hoar up error-They produce hypocrify and prevarication - They lay an undue byars on the human mind in its enquiries, and obstruct the progrefs of truth.-Genuine religion is a concern that lies entirely betwcen God and our own fouls. It is incapable of receiving any aid from human laws. It is contaminated, as foon as worldly motives and fanctions mix their influence with it. Statermen thould countenance it only by exhibiting in their own example a confcientions regard to it in thoie forms which are moft agreeable to their own judgments, and by encouraging their fellow-citizens in doing the fame. They camot as public men give

$$
\mathrm{F} 2
$$




\section{$\left[\begin{array}{ll}3^{6} & ]\end{array}\right.$}

it any other affinance. All befides that has been called a pubbic leading in religion, has done it an effential injury, and produced fome of the worf confequences.

The Church Eftablithment in Englund is one of the mildeft and beft fort. But even , here what a fnire has it been to integrity? And what a check to free enquiry? What difpofitions favourable to defpotifm has it foftered? What a turn to pride and narrownefs and domination has it given the clerical character? What ftruggles has it produced in its members to accommodate their opinions to the fubfcriptions and tefts which it impoles? What a perverfion of learning has it occafioned to defend obfelete creeds and abfurdities? What a burthen is it on the confciences of fome of its beft clergy, who, in confequence of being bound down to a fyftem they do not approve, and having no fupport except that which they derive from conforming to it, find themfelves under the hard neceffity of either prevaricating or farving? - No one doubis but that the Englim clergy in general could with i more truth declare that they do not, than that they do give their unfeigned affent to 


\section{[ 37 ]}

sill and every tbing contained in the thirtynine Articles and the Book of CommonPrayer; and yet, with a folemn declaration to this purpore, are they obliged to enter upon an office which above all offices requires thofe who exercife it to be examples of fimplicity and fincerity. - Who can help execrating the caufe of fuch an evil ?

But what I wifh mort to urge is the tendency of religious eftablifhments to impede the improvement of the world. They are boundaries prefcribed by human folly to human inveftigation; and inclofures which intercept the light and confine the exertions of reafon. Let any one imagine to himfelf what effects fimilar eftablinments would have in Philofophy, Navigation, Metaphyficks, Medicine or Mathematicks. Something like this took place in Logick and Philorophy; while the IPSE DIXIT of Ariftotle and the nonfenfe of the fchools maintained an authority like that of the creeds of cinurchmen: And the effect was a longer continuance of the world in the ignorance and barbarity of the dark ages. But civil eftablifhments of religion are more pernicious. So apt are mankind to mifreprefent the character of 


\section{[ $\left.3^{8}\right]$}

the Deity, and to corineet his favour with particular modes of faith, that it mutt be expected, that a religion fo fettled will be what it has hitherto been - a gloomy and cruel fuperftition bearing the name of religion.

It has been long a fubject of difpute, which is worft in its efrects on fociety, fuch a religion or fpeculative Atheifm. For I my own part, I could almoft give the preference to the latter.- A THEISM is fo repugnant to every principle of common fenfe, that it is not poffibie it thould ever gain much ground, or become very prevalent. On the contrary; there is a particular pronenefs in the human mind to Superstition, and nothing is more likely to become prevalent.-A - A theism leaves us to the full infuence of moft of our natural feelings and focial principles; and thefe are fo frong in their operation, that in general they are a fufficient guard to the order of fociety. But isuperstition counterass theie principles, by holding forth men to one another as objects of divine hatred; and by putting them on harrafing, filencing, imprifoning and burning one anotier in orcer to do God fervice.-A Thisisa is a fanctuary for 


\section{[ 39 ]}

vice by taking away the motives to virtue arifing from the will of God and the fear of a future judgment. But Superstition is more a fanctuary for vice, by teaching men ways of pleafing God without moral virtue, and by leading them even to compound for wickednefs by ritual fervices, by bodily penances and mortifications, by adorning thrines, going pilgrimages, faying many prayers, receiving abfolution from the prieft, exterminating heretics, \&c.-A тнEIsm deftroys the facrednefs and obligation of an oath. But has there not been alfo a religion (fo called) which has done this, by leading its profefiors to a perfuafion that there exifts a power on earth which can difpenfe with the obligation of oaths, that pious frauds are right, and that faith is not to be kept with heretics?

It is indeed only a rational and liberal religion; a religion founded on juf notions of the Deity as a being who regards equally every fincere worhipper, and by whom all are alike favoured as far as they act up to the light they enjoy; a religion which confints in the imitation of the moral perfections of an almighty but benevolent governor of nature, who directs for the befi. 


\section{[ 40 ]}

beft all events, in confiderice in the care of his providence, in refignation to his will, and in the faithful difcharge of every duty of piety and morality from a regard to his authority and the apprehenfion of a future righteous retribution.-- It is only $\mathrm{THIS}$ religion (the infpiring principle of every thing fair and worthy and joyful, and which in truth is nothing but the love of God and man and virtue warming the heart and directing the conduct.) - It is only THIs kind of religion that can blefs the world, or be an advantage to fociety.This is the religion that every enlightened friend to mankind will be zealous to promote. But it is a religion that the powers of the world know little of, and which will always be beft promoted by being left free and open.

I cannot help adding here, that fuch in particular is the Cbrifian religion.Chriftianity teaches us that there is none good but one, that is ${ }_{\lambda}$ God; that he willeth all men to be fived, and will punith nothing but wickednefs; that he defires mercy and not facrifice (benevolence rather than rituals) ; that loving him with all our hearts, and loving our neighbour as ourfelves, is the whole of our duty; and that in every 


\section{[ 4 I $]$}

nation he that feareth him and worketh righteoufiners is accepted of him. It refs its authority on the power of God, not of man; refers itrelf entirely to the underPtandings of men; makes us the fubjects of a kingdom that is not of this world; and requires us to elevate our minds above temporal emoluments, and to look forwards to a ftate beyond the grave, where a governsnent of perfect virtue will be erected under that Mefliah who has tafted dieath for every man.- What have the powers of the world to do with fuch a religion?-It difclaims all connexion with them; it made its way at firt in oppofition to them; and, as far as it is now upheld by them, it is dimonoured and vilified.

The injury which civil efablifhments do to Chriftianity may be learnt from the following confiderations.

Firn. The fpirit of religious eftablifhments is oppofite to the fpirit of Chriltianicy. It is a fpirit of pride and tyranny in oppofition to the Chriftian lowly fpirit; a contracted and felfin fpirit, in oppofition to the Chrifian enlarged and benevolent fpirit; the fuirit of the world in oppofition to the Curitian beavenly fpirit. 


\section{[ 42 C $]$}

Secondily. Religious eftablihments are founded on a claim of authority in the Chriftian church which overthrows Chrift's authority. He has in the foriptures given his followers a code of laws, to which he requires them to adhere as their only guide, But the language of the framers of church eftablimments is-We bave aubority in con"troverfics of faith, and power to decree rites "and ceremonies. We are the deputies of "Chrift upon earth, who have been com" mifioned by him to interpret his laws, "and to rule his church. You muft there-

- "fore follow US. The fcriptures are infuf"ficient. Our intepretations you muat "receive as Chrift's laws; our creeds as "bis doctrine; our inventions as bis in" ftitutions."

It is evident, as the excellent HoADLY has thewn, that thefe claims turn Chrift 1 out of the govermment of his own kingdom, and place ufurpers on his throne.They are therefore derogatory to his honour; and a rubmiffion to them is a breach of the allegiance due to him. They have been almon fatal to true Chriftianity; and attempts to enforce them $b_{y}$ civil penalties, 


\section{[ 43 ]}

have watered the Chriftian world with the blood of faints and martyrs.

Thirdly. The dificulty of introducing alterations into church eftablinments after they have been once formed, is another objection to them. Hence it happens, that they remain always the fame amidn all changes of public manners and opinions:; and that a kingdom even of Chriftans may go on for ages in idolatrous worhip, after a general conviction may have taken place, that there is but one being who is the proper object of religious adoration, and that this one being is that one only living and true God who fent Chrift into the wurld, and who is bis no lefs than he is our God and father. What a fad fcene of religious hypocrify mult fuch a difcordance between public conviction and the public forms produce?

* This is an inconvenience attending civil as well as , ecclefiafical eftablifhments, which has been with great wifdom guarded againft in the new Ancitican conftitutions, by appointing that there fhall be a revifal of them at the end of certain terms. This will leave them always open to improvement, without any danger of thofe convulfions which have ufually attended the corrections of abufes when they have acquired a facrednefs by time.

$$
\mathrm{G}_{2} \quad A
$$




\section{[ 44 ]}

At this day, in fome Europen countries, the abfurdity and favilhnefs of their hierarchies are feen and acknowledged; but being incorporated with the Rate, it is fcarcely pofitible to get rid of them.

What can be more friking than the State of Englond in this retpect?-The fyfem of faith and worthip eftablifhed in it was formed above two hundred years ago, when - Europe was juft emerging from darknefs and barbarity. The times have ever fince been growing more enlightened; but without any effect on the eftablichment. Not a ray of the increafing light has penetrated it. Not one imperfection, however grofs, has been removed. The fame articles of faith are fubfribed. The fame ritual of devotion is practifed. - There is reafon to fear that the abfolution of the fick, which forms a part of this ritual, is often reforted to as a paffport to heaven after a wicked life; and yet it is continued.-Perhaps nothing 1 more frocking to reafon and humanity ever made a part of a religious fyftem than the damning claules in the fithonafun creed; and yet the obligation of the clergy to declare afient to this creed, and to read it as a part of the public devotion, remains.

The 


\section{$\left[\begin{array}{lll}4 & 3\end{array}\right]$}

The neceflary confequence of fuch a tate of things is, that,

Fourthly, Chriftianity itfelf is difgraced, I and that all religion comes to be confidered as a ftate trick, and a barbarous mummery. It is well known, that in fome Popilh countries there are few Chriftians among the higher ranks of men, the religion of the State being in thofe countries mifaken. for the religion of the Gorpel. This indeed thews a criminal inattention in thofe who fall into fuch a miftake; for they ought to confider that Chrifianity has been grievoufly corrupted, and that their ideas of it fhould be taken from the New Teftament only. It is, however, fo natural to reckon Chrifianity to be that which it is held out to be in all the eftablifhments of it, that it cannot but happen that fuch an error will take place and produce fome of the worft confequences.- There is probably a greater number of rational Chriftians (that is, of Chriftians upon enquiry) in Englond, than in all Popifn countries. The reafon is, that the religious citablifhment here is Popery reformed; and that a confiderable body diffent from it, and are often inculcating the necefity of diftinguifhing 


\section{[ 4.6 ]}

guifing between the Chrifianity eftablined by law and that which is taught in the Bible.-Certain it is, that till this diftinction is made, Chriftianity can never recover its juft credit and ufefulnefs.

Such then are the effects of civil eftablifhments of religion. May heaven foon put an end to them. The world will never be generally wife or virtuous or happy, till thefe enemies to its peace and improvement are demolifhed. Thanks be to God, they are giving way before increafing light. Let them never thew themfelves in America. Let no fuch monfter I be known there as HUMAN AU'THORITY in MATTERS OF RELIGION. Let every honeft and peaceable man, whatever is his faith, be protected there; and find an effectual defence againft the attacks of bigotry and intolerance.-In the united States may Religion flourith. They cannot be very great and happy if it does not. But let it be a better religion than moft of thefe which have been hitherto profeffed in the world. Let it be a religion which enforces moral obligations; not a religion which relaxes and evades them. $-\mathrm{A}$ tolerant and $\mathrm{Ca}$ - 


\section{[ 47 ]}

tbolic religion; not a rage for profelitifm.A religion of peace and charity; not a religion that perfecutes, curfes and damns. - In a word, let it be the genuine Gorpel of peace lifting above the world, warming the heart with the love of God and his creatures, and furtaining the fortitude of good men by the affured hope of a future deliverance from death, and an infinite reward in the everlafing kingdom of our Lord and Saviour.

From the preceding obfervations it may be concluded, that it is impoffible I hould not admire the following article in the declaration of rights which forms the foundation of the Maffachufett's conftitution."In this State every denomination of "Chriftians demeaning themfelves peace" ably and as good fubjects of the com" monwealth, Mall be EQUALLY under the " protection of the law; and no fubordi" nation of any one fect or denomination " to another fhall ever be eftablined by "law *."

* The North Carolina conftitution alfo orders that there fhall be no eftablifhment of any one religious church or denomination in that State in preference to any other. 


\section{$\left[\begin{array}{lll}4 & \\ 4 & \end{array}\right]$}

This is liberal beyond all example. - I mould, however, have admired it more had it been MORE liberal, and the words ALI MEN OF ALL RELIGIONs been fubftituted for the words every denomination of Cibriflions.

It appears farther from the preceding obfervations, that I cannot but difike the 1 religious tefts which make a part of feveral of the American conftitutions.-In the Madichufet's confitution it is ordered, that all who take feats in the Houfe of Reprefentarives or Senate hall declare " their "firm perfuation of the truth of the "Chrifian reigion." The fame is required by the Maryland confitution, as a condition of being admitted into any places of profit o: truft. In Penfylonia every menber of the Houle of Reprefentatives is required to declare, that he " acknow"ledges the Scriptures of the Old and "New Tolament to be given by divine " infpiration." In the State of Delaware, that "he belicues in Cod the Father, and " in Jefus Chrift his only Son, and in the " Holy Ghor, one God blened for ever" more." All this is more than is re1 quired cven in England, where, though every 


$$
\text { [ } 49 \text { ] }
$$

every perfon however debauched oi atheiftical is required to receive the facrament as a qualification for inferior places, no other religious teft is impoled on members of parliament than a declaration againit Popery. -It is an obfervation no lefs juft than common, that fuch tefts exclude only boneft men. The dishoneft never foruple them.

Montescuieu probably was not a Chrifian. NEwTon and Locke were not Irinitarians; and therefore not Chriftians according to the commonly received ideas of Chriftianity. Would the United States, for this reafon, deny fuch men, were they living, all places of trult and power among them? 


\section{[ $5 \circ]$}

\section{Of Endcation.}

$\mathrm{SUCH}$ is the ftate of things which I winh to take place in the united American States. - In order to introduce and perpetuate it, and at the fame time to give it the greatert effect on the improvement of the world, nothing is more neceffary than the eftablifhment of a wife and liberal plan of Education. It is impofible properly to reprefent the importance of this. So much is left by the author of nature to depend on the turn given to the mind in early life, and the imprefitions then made, that I have often thought there may be a I fecret remaining to be difcovered in education, which will caufe future generations to grow up virtuous and happy, and accelerate human improvement to a greater degree than can at prefent be imagined.

The end of cducation is to direct the powers of the mind in unfolding themfelves; and to aiift them in gaining their juft bent and force. And, in order to this, 


\section{[ $5 \mathrm{I}$ ]}

its bufinefs thould be to teach bow to think, rather than what to think; or to lead in to the beft way of fearching for truth, rather than to inftruct in truth itfelf.-As for the latter, who is qualified for it?-There are many indeed who are eager to undertake this office. All parties and fects think they have difcover-, ed truth, and are confident that they alone are its advocates and friends. But the very different and inconfiftent accounts they give of it demonfrate they are utter ftrangers to it; and that it is better to teach nothing, than to teach what they hold out for truth. The greater their confidence, the greater is the reafon for diftrufting them. We generally fee the warmet zeal, where the object of it is the greatent nonfenfe.

Such obfervations have a particular tendency to thew that education ought to be an initiation into candour, rather than into, any fyftems of faith; and that it Mould form a habit of cool and patient inveltigation, rather than an attachment to any opinions.

But hitherto education has been conducted on a contrary plan. It has been a contration, not an enlargement of the $\mathrm{H}_{2}$ in - 


\section{[ $5^{2}$ ]}

intellectual faculties; an injection of falfe principles hardening them in error, not a difcipline enlightening and infroving them. Infead of opening and firngthening them, and teaching to think frecly; it hath cramped and enfaved them, and qualified for thinking only in one track. Infead of infilling humility, charity, and liberality, and the preparing for an eafier difcovery and a readier admiffion of truth; it has inflated with conceit, and ftuffed the human mind with wretched prejudices.

The more has been learnt from fuch education, the more it becomes neceffary to zinlearn. The more has been taught in this way, of fo much the more muft the mind be emptied before true wifdom can enter.-Such was education in the time of the firft teachers of chriftianity. By furnifhing with fkill in the arts of difputation and fophiftry, and producing an attachment to eftablifhed fyftems, it turned the minds of men from truth, and rendered them more determined to refif evidence and more capable of evading it. Hence it happened, that this heavenly inftruction, when firft 


\section{[ 53 ]}

communicated, was to the Feres a funbling block, and to the Greeks foolifinefs; and that, in fpite of miracles themfelves, the perfons who rejected it with moft difdain, and who oppofed it with moft violence, were thofe who had been educated in colleges, and were beft verfed in the falfe learning of the times: And had it taught the true philofophy inftead of the true religion, the effect would have been the fame. The doctrine "that the fun ftood ftill, and that " the earth moved round it," would have been reckoned no lefs abfurd and incredible, than the doctrine of a crucified Meffals. And the men who would have treated fuch an inftruction with moft contempt, would have been the roife and the prudent; that is, the proud fophifts and learned doctors of the times, who had fudied the Ptolemaick fyitem of the world, and learnt, by cycles and epicycles, to account for all the motions of the heavenly bodies.

In like manner, when the improvement of Logick in Mr. Locke's Effiy ors the Human Underftanding was firft publiched in Britain, the perfons readieft to attend to it and to receive it were thofe who had 


\section{[ 54 ]}

never been trained in colleges; and whofe minds, therefore, had never been perverted by an infruction in the jaryon of the fchools. To the deep profeflors of the time, it appeared (like the doctrine taught in his book on the Reaforablenefs of Chriftianity) to be a dangerous novelty and herefy; and the Univerfity of OxI FORD, in particular, condemned and reprobated the author.-W - The like happened when Sir IsaAC NEwTon's difcoveries were firft publithed. A romance (that is, the Philorophy of DESCARTES) was then in pofreftion of the philofophical world. Education had rivetted it in the minds of the learned; and it was twenty-feven years before Newton's Principia could gain fitficient credit to bring it to a fecond ' cdition. - Such are the prejudices which have generally prevailed againn new lights. Such the impediments which have been thrown in the way of improvement by a narrow plan of education.-Even now the principal object of education (efpecially in divinity) is to teach eftablified fyftems as certain truths, and to qualify for fuccersfully defending them araind opponents; 


\section{[ 55 ]}

and thus to arm the mind againft conviction, and render it impenetrable to farther light. Indeed, were it offered to my option which I would have, the plain fenfe of a common and untutored man, or the deep erudition of the proud fcholars and profeffors in moft univerfities, I hould eagerly prefer the former, from a perfuafion that it would leave me at a lefs diftance from real vifdom. An unoccupied and fimple mind is infinitely preferable, to a mind warped by fyftems; and the entire want of learning better than a learning, fuch as moft of that is which hitherto has been fought and admired-A learning which puffs up, while in reality it is nothing but profounder ignorance and more inveterate prejudice.

It may be worth adding here, that a narrow education (hould it ever happen not to produce the evils now mentioned) will probably produce equal evils of a contrary nature. I mean, that there will be danger, when perfons fo educated come to fee the abfurdity of fome of the opinions in which they have been educated, that they will become prejudiced againft them all, and, confequently, throw them all away, and 


\section{$\left[\begin{array}{ll}56 & 6\end{array}\right]$}

run wild into fcepticirm and infidelity. At prefent, in this part of the world this is a very common event.

I am by no means qualified to give a juft account of the particular method in which education ought to be conducted, fo as to avoid thefe evils: That is, fo as to rende: the mind free and unfettered; quick in difcerning evidence, and prepared to follow it from whatever quarter and in whatever manner it may offer itfelf. But certain it is, that the beft mode of education is that which does this moft effectually; which guards beft againft filly prejudices; which enflames moft with the love of truth; which difpofes moft to ingenuity and fairnefs; and leaves the mind moft fenfible of its own need of farther information. - Had this been always the aim of education, mankind would now have been farther advanced. It fuppores, however, an improved ftate of mankind; and when once it has taken place, it will quicken the progrefs of $i m-$ provement.

I have in thefe obfervations exprefled a difike of fyftems; but I have meant only 


\section{[ 57 ]}

to condemn that attachment to them as ftandards of truth which has been too prevalent. It may be neceffary in education to make ufe of them; or of books explaining them. But they fhould be ufed only , as guides and helps to enquiry. Infruction in them hould be attended with a fair exhibition of the evidence on both fides of every queftion; and care fhould be taken to induce, as far as pofible, a habit of believing only on an overbalance of evidence; and of proportioning afent in every cafe to the degree of that overbalance, without regarding authority, antiquity, fingularity, novelty, or any of the prejudices which too commonly infuence affent.-Wothing is fo well fitted to produce this habit as the fludy of matbematics. In thefe feiences no one ever thinks of giving his aflent to a propofition till he can clearly underftand it, and fee it proved by a fair deduction from propofitions previouny underfood and proved. In thefe fciences the mind is inured to clofe and patient attention; fhewn the nature of juft reafoning; and taught to form diftinct ideas, and to expect clear evidence in all cafes before belief. They furnith, therefore, the beft exercife for the intellec. 


\section{[ $\left.5^{8}\right]$}

tual powers, and the bett defence againf that credulity and precipitation and confufion of ideas which are the common fources of error.

There is, however, a danger even here to be avoided. Mathematical ftudies may abforb the attencion too much; and when they do, they contract the mind by rendering it incapable of thinking at large; by difqualifying it for judging of any evidence except mathematical; and, confequently, difpofing it to an unreafonable fcepticifm on all fubjects which admit not of fuch evidence.- - There have been many inftances of this narrowners in mathematicians.

But to return from this digreffion, - I cannot help obferving on this occafion, with refpect to CHRISTIANITY in particular, that education ought to lead to a habit of judging of it as it is in the code itfelf of Chriftianity; that the doctrines it reveals thould be learnt only from a critical and fair enquiry into the fenfe of this code; and that all inftuction in it nould be a preparation for making this enquiry and a communication of affiftance in examining into the proofs of its divine original, and in determining to what degree of evidence 


\section{[ 59 ]}

evidence thefe proofs amount, after ailowing every difficulty its juft weight. This has never yet been the practice among Chriftians. The New Teftament has been reckoned hitherto an infuficient Randard of I Chriftian Divinity; and, therefore, formularies of human invention pretending to explain and define it (but in reality mifreprefenting and dihonouring it) have been fubftituted in its room; and teaching tbefs has been called teaching Chrifumity. And it is very remarkable, that in the Englijh Univerfities Lectures on the New Tefta-, ment are feldom or ever read; and that, through all Chriftendom, it is much lefs an object of attention than the fyfems and creeds which have been fathered upon it.

I will only add on this fubject, that it is above all things neceffary, while infruction is conveyed, to convey with it a jenfe of the imbecility of the human mind, and of its great pronerefs to error; and allo a difpofition, even on points which feem the moft clear, to liften to objections, and to confider nothing as involving in it our fical. intereft but an HONEST HEART。

I 2 Nature 


\section{[60]}

Nature has fo made us, that an attach- ment mut take place within us to opinions once formed; and it was proper that we thould be fo made, in order to prevent that levity and defultorinefs of mind which mut have been the confequence had we been ready to give up our opinions too eafily and haftily. But this natural tendency, however wifely given us, is apt to exceed its proper limits, and to render us unreafonably tenacious. It ought, therefore, like all our cther natural propenfities, to be carefully watched and guarded; and education thould put us upon doing this. An obfervation before made fhould, in partit cular, be inculcated, "that all mankind "s have hitherto been molt tenacious when " mort in the wrong, and reckoned them"felves monenlightened when moft in the " dark."-- This is, indeed, a very mortifying fact; but attention to it is neceffary to cure that miferable pride and dogmaticalnefs which are fome of the wornt enemies to improvement. - Who is there that does not remember the time when he was cotirely fatisfied about points which deeper referion has hewn to be above his comprehenfion? Who, for inftance, does not 


\section{[ 61 ]}

not remember a time when he would have wondered at the queftion, "why does "water run down hill ?" What ignorant man is there who is not perfuaded that he underftands this perfectly? But every improved man lnows it to be a queftion he cannot anfwer; and what diftinguifhes him in this infance from the lefs improved part of mankind is his knowing this. The like is true in numberlefs other inftances. One of the beft proofs of wifdom is a fente of our want of wifdom: and he who knows moft porfefies mont of this fenfe.

In thinking of myself I derive fome encouragement from this reflexion. I now fee, that I do not underftand many points, which once appeared to me very clear. The more I have inquired, the more fenfible I have been growing of my own darknefs; and a part of the hiftory of my life is that which follows.

In early life I was fruck with Bifhop Butier's Analogy of religion natural and revealed to the confitution and courfe of naw ture. Ireckon it happy for me that this book 


\section{[ 62 ]}

book was one of the firft that fell into my hands. It taught me the proper mode of reafoning on moral and religious fubjects, and particularly the importance of paying a due regard to the imperfection of human knowledge. His Sermons alfo, I then thought, and do ftill think, excellent,

- Next to bis works, I have always been an admirer of the writings of Dr. C LAKK. $_{\text {. }}$ And I cannot help adding, however ftrange it may feem, that I owe much to the philofophical writings of Mr. HuME, which I likewife Atudied early in life. Though an enemy to his Scepticifm, I have profited by it. By attacking, with great ability, every principle of truth and reafon ${ }_{2}$ he put me upon examining the ground upon which I ftood, and taught me not battily to take any thing for granted.- - The firft fruits of my reading and nudies were laid before the public in a Treatife entitied $A$. REview of the principal Quefions and Difficulties in Morals. This publication has been followed by many others on various fubjects.-And now, in the evening of a life devoted to enquiry and fpent in endeavours (weak indeed and feeble) to ferve 


$$
\left[\begin{array}{ll}
6 & 6
\end{array}\right]
$$

the beft interefts, prefent and future, of mankind, I am waiting for the GREAT, TEACHER, convinced that the order of nature is perfect; that infinite wifdom and goodneis govern all things; and that Chriftianity comes from God : But at the fame time puzzled by many difficulties, anxious for more light, and refting with full and conftant affurance only on this ONE truth - That the practice of virtue , is the duty and dignity of man; and, in all events, his wifert and fafert courfe. 


\section{$\left[\begin{array}{ll}6 & 0\end{array}\right.$}

Of the Dangers to which the Americait States are expofed.

IN the preceding obfervations, I have aimed at pointing out the means of promoting the progrefs of improvement in the united States of America. I have infifted, particularly, on the importance of a jur fettlement of the FEDERAL UNION, and the eftablifhment of a well-guarded and perfect liberty in fpeculation, in government, in education, and in religion. The united States are now fetting out, and all depends on the care and forefight with which a plan is begun, which hereafter will require only to be firengthened and ripened. This is, therefore, the time for giving them advice; and mean advice (like the prefent) may fuggeft fome ufeful hints. - In this country, when any improvements are propofed, or any corrections are attempted of abufes fo grofs as to make our boafts of liberty ridiculous *, a clamour

* The majority of the Britrse Houfe of Coma mons is chofen by a few thoufands of the dregs of the pcople, who are conftantly paid for their votes.- 


\section{$\left[\begin{array}{lll}6 & 6 & 1\end{array}\right]$}

clamour immediately arifes againft INNOVATION; and an alarm fpreads, left the attempt to repair thould defroy. In America no fuch prejudices can operate. There abufes have not yet gained facrednefs by time. There the way is open to focial dignity and happinefs; and reafon may utter her voice with confidence and fuccefs.

Is it not ridiculosts to call a country fo governed free? See a ftriking account of the State of the Britifh Parliamentary Reprefentation, in Mr. Burgh's Political Difquifitions, Vol. I. p. 39, \&c.

It was propofed to the convention for fettling the Maffachufett's conftitution, that one of the two houfes which conftitute the general court of that State fhould be a reprefentation of perfons, and the other a reprefentation of property; and that the body of the people fhould appoint only the eleztors of their reprefentatives.-By fuch regulations corruption in the choice of reprefentatives would be rendered lefs practicable; and it feems the beft method of concentering in the Legiflature as much as poffible of the virtue and ability of the State, and of making its voice always an expreflion of the will and beft fenfe of the people.- $\mathrm{On}_{\mathrm{n}}$ this plan alfo, the number of members conftituting a Leginature might be much leffened.-This is a circumftance of particular confequence, to which the united States, in fome future period of their increafe, will find it neccffary to attend. It has been often juftly obferved, that a legiflative body very numerous is little better than a mob. 
Of DEBTS and INTERNAL WARS.

Tlave obferved in the introduction to this Addrefs, that the American States have many dangers to fhun. In what follows I thall give a brief recital of fome of the chief of there dangers.

The danger from an endlefs increafe of PUBLIC DEBTS has been already fufficiently noticed.

Particular notice has been likewife taken of the danger from inTERNAL WARS.Agnin and agnin, I would urge the neceffity of purfuing every meafure and ufing every precaution which can guard againft this danger. It will be hocking to fee in the new world a repetition of all the evils which have hitherto laid wafte the old world - Var raging where peace and liberty were thought to have taken their abodes - The points of baycnets and the mouths of cannon fettling difputes, intead of the collected wifdom of the confederation - and perhaps cice reflefs and ambitious State rifing by bloody 


\section{$\left[\begin{array}{ll}6 & 6\end{array}\right]$}

bloody conquent above the reft, and becoming a fovereign State, claiming impiouny (as Britain once did) "full authority to make, " laws that thall bind its fifter Statcs in all " cafes whatever," and drawing to itfelf all advantages at their expence.-. I deprecate this calamity. I thudder when I confider how poflible it is ; and hope thofe perfons are miltaken who think that fuch are the jealoufies which govern human nature, and fuch the imperfections of the beft human arrangements, that it is not within the reach of any wifdom to difcover any effectual means of preventing it, without encroaching too much on the liberty and independence of the States. I have mentioned an enlargement of the powers of Congress. Others have propofed a confolidation of the powers of government in one Pardiament reprefenting all the States, and fuperfeding the particular parliaments by which they are now feparately governed. But it is obvious, that this will be attended with greater inconveniencies, and encroach more on the liberty of the States, than the enlargement I have propofed of the powers of CONGRESS. If If 


\section{[ 68 ]}

fuch a parliament is not to fuperfede any of the other parliaments, it will be the fame with CONGRESS as at prefent conftituted.

\section{Of an veneual Distribution of PROPERTY.}

$T T$ is a trite obfervation, that "dominion I " is founded on property." Molt free States have manifefted their fenfe of the truth of this obfervation, by nudying to find out means of preventing too great an inequality in the diftribution of property. What tumults were occafioned at Rome, in its beft times, by attempts to carry into execution the Agrarian law ? Among the people of Ifrael, by the direction of heaven, all eftates which had been alienated during the courfe of fifty years, returned to their original owners at the end of that term. One of the circumftances that has been molt favourable to the American States in forming their new conftitutions of government has been the equality which fubfifts among them. 


\section{[ 69 ] ]}

The happieft fate of man is the middle Itate between the favage and the refined, or between the wild and the luxurious frate. Such is the tate of fociety in CONAECTICUT, and fome others of the American provinces; where the inhabitants confint, if I am rightly informed, of an independent and hardy YEOMANRY, all nearly on a level-trained to arms,-inftructed in their rights-cloathed in home-fpun-of fimple manners - Atrangers to luxury - drawing plenty from the ground-and that plenty, gathered eafily by the hand of induftry; and giving rife to early marriages, a numerous progeny, length of days, and a rapid increafe-the rich and the poor, the haughty grandee and the creeping fycophant, equally unknown-protected by laws, which (being their own will) cannot opprefs; and by an equal government, which wanting lucrative places, cannot create corrupt canvaffings * and ambitious intrigue. $-\mathrm{O}$ diftinguihed people! May you continue

* In this State, and alfo the State of Mafachufetts, I New Ferfey, \&c. any attempt to canvas, or even the expreffion of a wilh to be chofen, will exclude a candidate from a feat in the Houfe of Reprefentatives. The fame is true of any tain on his moral character.

long 


\section{[ 70 ]}

long thus happy; and may the happinefs you enjoy fpread over the face of the whole carth!-But I am forgetting myfelf. There is danger that a ftate of fociety fo happy will not be of long duration; that fimplicity and virtue will give way to depravity; that equality will in time be lon, the curfed luft of domineering thew itfelf, liberty languirh, and civil government gradually degenerate into an inferument in the hands of the few to opprefs and plunder the many.-Such has hitherto been the progrefs of evil in human affairs. In order to give them a better turn, fome great men (Plato, Sir Thomas 'More, Mr. Wallace, \&c.) have propofed plans, which, by eftablinhing a community of goods and annihilating property, would make it impoffible for any one member of a State to think of enflaving the reft, or to confider himfelf as having any intereft difinct from that of his fellow-citizens. Such theories are in fpeculation pleafing; nor perhaps are they wholly impracticable. Some approaches to them may hereafter be made; and fchemes of government may take place, which thall leave fo little, befides perfonal merit, to be a means of diftinction, 


\section{$\left[\begin{array}{ll}71 & ]\end{array}\right.$}

as to exclude from fociety moft of the caufes of evil. But be this as it will; it is out of doubt that there is an equality in fociety which is effential to liberty, and which 1 every State that would continue virtuous and happy ought as far as poffible to maintain. - It is not in my power to defcribe the beft method of doing this. - I will only obferve, that there are THREE enemies to equality againft which Aizerica ought to guard.

Firft; Granting hereditary honours and, titles of nobility. Perfons thus diftinguinhed, though perhaps meaner than the meaneft of their dependents, are apt to confider themfelves as belonging to a higher order of beings, and made for power and government. Their birth and rank neceffarily difpofe them to be hoftile to general liberty; and when they are not fo, and difcover a juft zeal for the rights of mankind, it is always a triumph of good fenfe and virtue over the temptations of their fituation. It is, therefore, with peculiar fatisfaction that I have found in the articles of confederation 1 an order that no titles of nobility thall be ever granted by the united States. Let 


\section{$\left[\begin{array}{ll}7^{2} & 3\end{array}\right.$}

there be honours to encourage merit; but let them die with the men who have earned them. Let them not defcend to pofterity to fofter a fpirit of domination, and to produce a proud and tyrannical ariftocracy. -In a word, let the united States continue for ever what it is now their glory to be-a confederation of States profperous and happy,

, without LorDs-without Bishops w-and without KInGs.

Secondly; The right of primogeniture. The tendency of this to produce an improper inequality is very obvious. The difpofition to raife a name, by accumulating property in one branch of a family, is a vanity no lefs unjuft and cruel, than

* I do not mean by Bißsops any officers among Chriftians merely fpiritual; but Lords Jpiritual, as diftinguifned fiom Lords temporal, or Clergymen raifed to preeminence, and invefted with civil honours and authority, by a State eftablifhment.

I muft add, that by what is here faid I do not mean to exprefs a gencral preference of a republican conftitution of government. There is a degree of political degeneracy which unfits for fuch a conflitution. Britain, I in particular, confifts too much of the high and the low, (of foun and dregs) to admit of it. Nor will it fuit America, fhould it ever become cqually corrupt. 


$$
\text { [73] }
$$

dangervus to the intereit of liberty; and no wife State will encourage or tolerate it.

Thirdly; Forelgn TRADE is another of the enemies againft which 1 wifh to caution the united States. But this operates unfavourably to a State in fo many more ways than by deftroying that equality which is the bafis of liberty, that it will be proper to take more particular notice of it. 


\section{$[5]$}

Of Trade, Banks, andPaper Credit.

H OREIGN trade has, in fome refpects, the moft ufeful tendency. By creating an intercourfe between diftant kingdoms, it extends benevolence, removes local prejudices, leads every man to confider himfelf more as a citizen of the world than of any particular State, and, confequently, jchecks the excefies of that Love of our Country which has been applauded as

one

* The jove of our country is then only a noble parfion when it engages us to promote the internal happineis of our country, and to defend its rights and liberties againf domeftic and foreign invafion, maintaining at the fame time an cqual regard to the rights and liberties of other countric:. But this has not been its moft common effects. On the contrary, it has in gencral been nothing but a fpirit of rivalfhip between different communities, producing contention and a thirft for conqueit and dominion. - What is his country to a Ruffan, a Turk, a saniard, Sic. but a fpot where he enjoys no sight, and is cifpolcu of by owners as if he was a beaft? And what is his love to his country but an atrachment to degraciution and fluvery ?-What was the love of their country anomg the ferus but a wretched partiality for thendulve wis a roud contempt for other nations? 


\section{$\left[\begin{array}{ll}75 & ]\end{array}\right.$}

one of the nobler, but which, really, is one of the moit deforative principles in human nature. - Trade alfo, by enabling every country to draw from other countries conveniencies and advantages which it cannot find within iticlf, produces among nations a fenfe of mutual dependence, and promotes the general improvement. - But there is no part of mankind to which thefe ufes of trade are of lefs confequence than the American States. They are fpread over a, great continent, and make a world within themielves. The country they inhabit includes foils and climates of all forts, producing not only every necefary, but every convenience of life. And the vaft rivers and wide-fpread lakes which interfect it, create fuch an inland communication between its different parts, as is unknown in any other region of the earth. They poffefs then within themlelves the

Among the Romans alfo what was it, however great in many of its exertions, but a principle holding together a band of robbers in their attempts to crum all liberty but their own?-Chriftianity has wifely omitted to recommend this principle. Had it cone this, it would have countenanced a vice among mankind.-It has done what is infuitely better - It has recummonded UNIVERSAL BENEYOLENCE. 


\section{$\left[\begin{array}{ll}76 & ]\end{array}\right.$}

beft means of the mott profitable traftic, and the ampleft fcope for it. Why fhould they look much farther? What occation have they for being anxious 'about pufhing foreign trade; or even about raifing a great naval force? - Britain, indeed, confifting as it does of unamed inhabitants, and threatened as it is by ambitious and powerful neighbours, cannot hope to maintain its exiftence long after becoming open to invafion by lofing its naval fuperiority. - But this is not the cafe with the American States. They have ' no powerful neighbours to dread. The vaft Atlantic mult be crofled before they can be attacked. They are all a welltrained militia; and the fuccefsful reinfance which, in their infancy and without a naval force, they bave made to the invaiton of the firt European power, will probably difcourage and prevent all future invafions. Thus fingularly happy, why hould they reek connexions with Earope, and expofe themfelves to the danger of being involved in its quatrels? - What have they to do with its politics? - Is there any thing very important to them which they can draw from thence-except InFEcTion?-In-, dect, $_{2}$ 


\section{[ 77 ]}

deed, I tremble when I think of that rage for trade which is likely to prevail among them. It may do them infinite mifchief. All nations are fpreading fnares for them, and courting them to a dangerous intercourfe. Their beit intereft requires them to guard themfelves by all proper means; and, particularly, by laying heary dutics on importations. But in no cale will any means fucceed unlets aided by Mraxers. In this inftance, particularly, there is reaton to fear that an increating paftion for foreign frippery will render all the beit regulations ineffectual. And fhould this happen, that fimplicity of character, that manlinets of fpirit, that difdain of tinfel in which true dignity confits, will difappear. Effeminacy, fervility and venaity will enter; and liberty and virtue be fwallowed up in the gulph of corruption. Such may be the courle of events in the American States. Betier infinitely will it be for, them to confen of bodies of plain and honelt farmers, than of opulent and fplendid merchants. - Where in thefe States do the pureft manners prevail? Where do the inhabitants live mort on an equality, and mat at their eafe? is 


\section{[ 78 ]}

it not in thofe inland parts where agricuiture gives health and plenty, and trade is fcarcely known ?-Where, on the contrary, are the inhabitants moft felfin, luxurious, loofe, and vicious; and at the fame time moft unbappy? Is it not along the fea coafts, and in the great towns, where trade flourifhes and merchants abound ?So Atriking is the effect of thefe different fituations on the vigour and happinefs of human life, that in the one population would languin did it receive no aid from emigrations; while in the other it increafes to a degree fcarcely ever before known.

But to proceed to fome obfervations of a different nature-

The united States have, I think, particular reafon to dread the following effects of foreign trade.

By increafing importation to feed lixury and gratify prodigality, it will carry out their coin, and occafion the fubftitution of a delufive paper currency; the confequence of which will be, that ideal wealth will take place of real, and their fecurity come to depend on the ftrength and duration of a Bubble. - I am very fenfible that paper. credit 


\section{[ 79 ]}

credit is one of the greatert of all conveniencies; but this makes it likewife one of the greatent of all temptations. A public Bank, (while it can circulate its bills) facilitates commerce, and aflifts the exertions of a State in proportion to its credit. But when it is not carefully reftricted and watched; when its emiffions exceed the coin it can command, and are carried near the utmoft length that the confidence of the public will allow; and when, in confequence of this, its permanence comes to depend on the permanence of public credulity - In thefe circumftances, a BANK, though it may for a time (that is, while a balance of trade too unfavourable does not occafion a run, and no events ariie which produce alarm) anfwer all the ends of a MINE from which millions may be drawn in a minute; and, by filling a kingdom with carh, render it capable of furtaining any debts, and give it a kind of OMNIPOTENCE. - In fuch circumfances, I fay, notwithftanding thefe temporary advantages, a public BANK muft at laf prove a great calamity; and a kingdom io fupported, at the very time of its greateft 


\section{[ 80 ]}

exertions, will be only friving more violently to increafe the horror of an approching convulfion.

The united States have already verified fome of theie obfervations, and felt in fome degree the confequences to which I have alluded. They have been carried through the war by an emiffion of paper which had no folid fupport, and which now has loft all value. It is indeed furprifing that, being fecured on no fund and incapable of being exchanged for coin, it thould ever have obtained a currency; or anfwered any important purpofe.

Unhappily for Britain, it has ufed the means of giving more ftability to its papercredit, and been enabled by it to fupport expences grcater than any that have been yet known, and to contract a debt which now afroniflus, and may hereafter produce a catantrophe that will terrify the world.A longer duration of the late war would have brought on this cataltrophe immediately. The PEACE has put it off for the prefent. God grant, if Atill poffible, that meafures may be adopted which hall put it off for ever. 


\section{$\left[\begin{array}{ll}B_{I} & \end{array}\right]$}

\section{Of O А тн}

O A HS are expedients to which all States have had recourfe in order to obtain true information and afcertain facts by fecuring the veracity of witnefies. But I know not how to relin that imprecation which always makes a part of an oath. Perhaps, there is no fuch neceffity for it as is commonly imagined. An Afrir-, MATION folemnly made, with laws inflicting fevere penalties on fallhood when detected, would probably anfwer all the ends of ouths. - I am, therefore, difpored to win, that in the united States imprecatory oaths may be abolifhed, and the fame indulgence in this refpect granted to all which is now granted to the Quakers. But I am afraid they will think this too dangerous an experiment; and what is of moft confequence is to avoid,

Firft, Such a multiplicity of oxths as will render them too familiar.

And, Secondly, A flight manner of adminifering them. ENGLAND, in this re$M$

fpect, 


\section{[ 82 ]}

ipect, feems to be funk to the loweft porfible degree of degeneracy. Oaths among us are required on fo many occafions, and fo carelefsly adminiftered, as to have lof almoft all their ufe and efficacy. It has been afferted, that, including oaths of office, oaths at elections, cuftom-houfe oaths, \&c. Ec. there are about a million of perjuries committed in this kingdom annually. - This is one of the moft atrocious of our national iniquities; and it is a wonder if we are not to be vinted for it with fome of the fevereft of God's judgments. 


\section{$\left[\begin{array}{ll}8_{3} & \end{array}\right]$}

Of the Negro Trade and Slavert.

$T$ He negro Trade cannot be cenfured in language too fevere. It is a traffick which, as it has been hitherto carried on, is hocking to humanity, cruel, wicked, and diabolical. I am happy to find that the united States are entering into , meafures for difcountenancing it, and for abolining the odious flavery which it has introduced. 'Till they have done this, it will not appear they deferve the liberty for which they have been contending. For it is felf-evident, that if there are any men whom they have a right to hold in flavery, there may be others who have had a right to hold tkem in flavery. * - I am fenfible, however, that this is a work which they cannot accomplifh at once. The emancipation of the Negroes muft, I fuppofe, be left in fome meafure to be the effect of

* See a remonfirance, full of energy, direced to the united States on this Subjckt, by a very warm and able friend to the rights of mankind, in a Track, entitledFragment of an origizal Lettir on the Slavery of the Negroes; written in the year 17,6 , but publifhed in 1784 , by Thomas Day, Efq. 


\section{$\left[\begin{array}{ll}8 & 8\end{array}\right]$}

time and of manners. But nothing can excufe the united States if it is not done with as much fpeed, and at the fame time with as much effeet, as their particular circumftances and fituation will allow. I rejoice that on this occafion 1 can recommend to them the example of my own - country. - In Britain, a Negro becomes a freman the moment he fets his foot on Britifl ground.

SUCH is the advice which I would bumbly. (but earnefty) offer to the united States of America. - Such are the means by which they may become the feats of liberty, fcience, peace, and virtue; bappy within themfelves, and a refuge to the world.

Often, while employed in writing thefe papers, have I withed for a warning voice of more power. The prefent moment, however aufpicious to the united States if wifely improved, is critical; and, though apparently the end of all their dangers, may

prove 


\section{$\left[\begin{array}{ll}8 & \end{array}\right]$}

prove the time of their greateft danger. I have, indeed, fince finilhing this Addrefs, been mortified more than I can exprefs by accounts which have led me to fear that I have carried $m y$ ideas of them too high, and deceived myfelf with vilionary expectations.- - And hould this be true - Should the return of peace and the pride of independence lead them to fecurity and difipation - Should they lofe thofe virtuous and fimple manners by which alone Republics can long fubfiftShould falfe refinement, luxury, and irreligion fpread anong them; exceffive jealoufy diftract their governments; and clahing interefts, fubject to no ftrong controul, break the federal union-The confequence will be, that the faireft experiment ever tried in human affairs will mifarry; and that a REvolution which had revived the hopes of good men and promifed an opening to better times, will become a difcouragement to all future efforts in favour of liberty, and prove only an opening to a new fcene of human degeneracy and mifery. 



\section{$\left[\begin{array}{lll}8 & 8\end{array}\right]$}

\section{A DVERTISEM E N T.}

THE following letter was written by the I late M. Turgot, Comptroller General (in the years 1774, 1775, and 1776) of the finances of FRANCE. It contains obfervations in which the United States are deeply concerned; and, for this reafon, I now convey it to them, not doubting but that the eminence of M. Turgot's name and character will recommend it to their attention, and that it will do honour to his memory among all the friends of public liberty. 


\section{[ 88 ] \\ $A$ Monfeur P R I C E, \\ A Londres.}

A Paris, le 22 Mars, 1778.

$M^{R}$. FRANKLIN m'a remis, Monfieur, de votre part, la nouvelle édition de vos obfervations fur la liberté civile, \&c. Je vous dois un double remerciment; $I^{\circ}$ de votre ouvrage dont je connois depuis longtems le prix, et que j'avois lu avec avidité, malgré les occupations multipliées, dont j'etois affailli, lorfqu'il a paru pour la premiere fois; $2^{\circ}$ de l'honnêteté que vous avez eue de retrancher l'imputation de maladreffe * que vous aviez mêlée au bien que vous difiez d'ailleurs de moi dans vos obfervations additionelles. J'aurois pu la meriter, fi vous n'aviez eu en vue d'autre maladrefie que celle de n'avoir pas fça demêler les refforts d'intrigues que faifoient jouer contre moi des gens beaucoup plus adroits en ce genre que je ne le fuis, que je ne le ferai jamais, et que je ne veux l'etre. Mais il m'a paru que vous m'imputiez la maladrefle d'avoir choqué groflierement l'opinion générale de

* See the Notes annexed to the Tranflation of this Letier. 


\section{[ 89 ]}

ma nation; et à cet égard je crois que vous n'aviez rendu juftice ni à moi, ni à ma nation, où il y a beaucoup plus de lumieres qu'on ne le croit généralement chez vous, et où peut-être il eft plus aifé que chez vous même de ramener le public à des idées raifonnables. J'en juge par l'infatuation de votre nation fur ce projet abfurde de fub-' juguer l'Amérique, qui a duré jufqu'à ce que l'aventura de Burgoyne ait commencé à lui deffiller les yeux. J'en juge par le fyftême de monopole et d'exclufion qui rêgne chez tous vos écrivains politiques fur le commerce, (J'excepte Mr. Adam Smith et le Doyen Tucker) fyftême qui eft le véritable principe de vatre féparation avec vos colonies. J'en juge par tous vos écrits polémiques fur les queftions qui vous agitent depuis une vingtaine d'années, et dans lefquels avant que le vôtre eut paru, je ne me rappelle prefque pas d'en avoir lu un, oi le vrai point de la queftion ait êté faifi. Je n'ai pas conçu comment une narion qui a cultivé avec tant de fuccès toutes les branches des fiences naturelles a pu refter fi fort au deffous d'elle même, dans la fcience la plus intereffante de toutes, celle du bonheur public; dans une fcicnce oi la liberté de la prefle, dont elle feule jout, 


\section{$\left[\begin{array}{ll}0 & 0\end{array}\right]$}

auroit dû lui donner fur toutes les autres nations de l'Europe un avantage prodigieux. En-ce l'orgueil national qui vous a empêchés de mettre à profit cet avantage? Elt-ce parce que vous etiez un peu moins mal que les autres, que vous avez tourné toutes vos fpéculations à vous perfuader que vous etiez bien? Eft-ce l'efprit de parti, et l'envie de fo faire un appui des opinions populaires qui a retardé ros progrès, en portant vos politiques à traiter de vaine métaphyfique toutes les fpéculations qui rendent à établir des principes fixes fur les dioits et les vrais interêts des individus et des nations? Comment fe fait-il que vous foyez prefque le premier parmi vos écrivains qui ayez donné des notions juftes de la liberté, et qui ayez fait fentir la fauffeté de cette notion rebattue par prefque tous les écrivains les plus républicains, que la liberté confifte à n'être foumis qu'aux luix, comme is un homme opprimé par une loi injufe etoit libre. Cela ne feroit pas même vrai guand on fuppoferoit que toutes les loix font l'ouvrage de la nation anconbié; car enfin l'individu a aufi des revits que la nation ne peut lui ôter, que par la violence ct par un urage illegitime de la force générale. Quoique vous ayez eu égrard 


\section{[ $9^{\mathrm{I}}$ ]}

égard à cette verité, et que vous vous en foyez expliqué, peut-être méritoit-clle que vous la dévelopafiez avec plus d'ctendue, vî le peu d'attention qu'y ont donnée même les plus zelés partifans de la liberté.

C'eft encore une chore étrange que ce ne fût pas en Angleterre une vérité triviale de dire qu'une nation ne peut jamais avoir droit de gouverner une autre nation; et qu'un pareil gouvernement ne peut avoir d'autre fondement que la force, qui eft auffi le fondement du brigandage et de la tyrannie; que la tyrannie d'un peuple eft de toutes les tyrannies connues la plus cruelle et la plus intolérable, celle qui laifie le moins de reffource à l'opprimé; car enfin un defpote ent arrêté par fon propre interêt, il a le frein du remords, ou celini de l'opinion publique, mais une multitude ne calcule rien, n'a jamais de remords, et fe decerne à elle même la gloire lors qu'elle mérite le plus de honte.

Les événemens font pour la nation Angloife un terrible commentaire de votre livre. Depuis quelques mois ils fe prëcipitent avec une rapidité très ac-

$$
\mathrm{N}_{2}
$$

celérée. 


\section{[ 992$]$}

celérée. Le dénouement eft arrivé par tapport à l'Amérique. La voila indépendante fans retour. Sera-t'elle libre et heureufe? Ce peuple nouveau firué fi avantageufement pour donner au monde l'exemple d'une conftitution où thommé jouiffe de tous fes oroits, exerce librement toutes fes facultés, et ne foit govverné que par la nature, la raifon et la juftice, faura-t'il former une pareille conflitution? faura-t'il l'afermir fur des fondemens éternels, prévenir toutes les caufes de divifion et de corruption qui peuvent la miner peu-à-peis et la détruire?

Je ne fuis point content je l'avoue des conftitutions qui ont êté rédigées jufqu'àpréfent par les différens Etats Américains. Vous reprochez avec raifon à celle de la Penfylvanie le ferment religieux exigé pour avoir entrée dans le corps des repréfentans. C'elt bien pis dans les autres; il y en a une, je crois que c'eft celle des Jerfeis qui exige

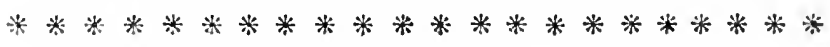
Je vois dans le plus grand nombre l'imitation fans objet des urages de l'Angleterre. Au lieu de ramener toutes les autorités à une feule, celle de la nation, l'on établit des corps différens, un corps des repréfentans, 


\section{[ 93 ]}

un confeil, un gouverneur, parce que l'Angleterre a une chambre des communes, une chambre haute et un Roi. On s'occupe a balancer ces différens pouvoirs; comme fi cet équilibre de forces, qu'on a pu croire neceffaire pour balancer l'énorme prépondérance de la Royauté, pouvoit être de quelque ufage dans des Républiques fondées fur l'égalité de tous les citoyens; et comme fi tout ce qui établit différens corps n'êtoit pas une fource de divifions. En voulant prévenir des dangers chimériques, on en fait naitre de réels; on veut n'avoir rien à craindre du clergé, on le réunit fous la barriere d'une profcription commune. En l'excluant du droit d'eligibilité, on en fait un corps, et un coress étranger à l'Etat. Pourquoi un citoyen, qui a le même interêt que les autres à la defenfe commune de fa liberté et de fes propriétés, eft-il exclus d'y contribuer de fes lumieres et de fes vertus, parce qu'il eft d'une profeffion qui exige des lumieres et des vertus? Le clergé n'eft dangereux que quand il exifte en corps dans l'Etat; que quand il croit avoir en corps des droits et des interêts, que quand on a imaginé d'avoir une religion établie par la loi, comme fi les hommes pouvoien 


\section{[ 94 ]}

pouvoient avoir quelque droit, ou quelque interet à régler la confcience les uns des antres; comme fi l'individu pouvoit facrifer aux avantages de la focieté civile les opinions auxquelles il croit fon falut éternel attaché; comme fi l'on fe fauvoit, ou fe damnoit, en commun. Là où la vraye tolérance, c'eft-à-dire l'incompétence ablolue du gouvernement fur la confcience des individus, eft établie, l'ecclefiaftique au milieu de l'affemblée nationale n'eft qu'un citoyen, lorfqu'il y eft admis; il redevient ecclefiatique lorfqu'on l'en exclut.

Je ne vois pas qu'on fe foit afiez occupé de réduire au plus petit nombre pofible, les genres d'affaires dont le gouvernement de chaque Etat fera chargé ; ni à féparer les objets de légillation, de ceux dadminifration générale et de ceux d'adminiftration particuliere et locale; à conftituer des affemblées locales fubfiftantes, qui rempliffant prefque toutes les fonctions de detail du gouvernement difpenfent les affemblées générales de s'en occuper, et ôtent aux membres de celles-ci, tout moyen, et peut-être tout défir d'abufer d'une autorité qui ne peut s'appliquer qu'à. 


\section{[ 95 ]}

des objets généraux et par là même étrangers aux petites pafions qui agitent les hommes.

Je ne vois pas qu'on ait fait attention à la grande diftinction la feule fondée fir la nature entre deux claffes d'hommes, celle des propriétaires de terres, et celle des nonpropriétaires; à leurs interets et par conféquent à leurs droits différens, relativement à la légillation, à l'adminiftration de la juftice et de la police, à la contribution aux dépenfes publiques et à leur emploi.

Nul principe fixe établi fur l'impôt; 013 fuppole que chaque province peut ic taxer à fa fantailie, établir des taxes perfonnelles, des taxes fur les confommations, fur les importations, c'eft-i-dire fe donner un interêt contraire à l'interêt des autres provinces.

On fuppofe par tout le droit de régler it commerce ; on autorife même les corps exucutifs, ou les gouverneurs ì prohiber l'exportation de certaines denrées dans certaines occurrences; tant on eft loin d'avoir ferti que la loi de la liberté entiere de tout con. merce eft un cerollaire du droit de pmo priété; tant on eft encose plongé divis le

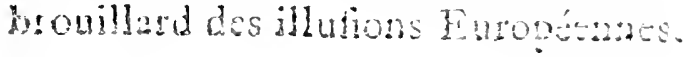




\section{$[96]$}

Dans l'union générale des provinces entre elles, je ne vois point une coalition, une fulion de toutes les parties, qui n'en fafle qu'un corps un, et homogene. Ce n'eft qu'une aggrégation de parties, toujours trop féparées, et qui confervent toujours une tendance à fe divifer, par la diverfité de leurs loix, de leurs mœurs, de leurs opinions; par l'inégalité de leurs forces actuelles; plus encore par l'inégalité de leurs progrès ultérieurs. Ce n'eft qu'une copie de la République Hollandoife; et celle-ci même n'avoit pas à craindre' comme la République Américaine les accroiffemens poffibles de quelques unes de fes provinces. Tout cet édifice eft appuyé jufqu'à préfent fur la bâfe faufe de la très ancienne et très vulgaire politique; fur le prejugé que les nations, les provinces, peuvent avoir des interêts, en corps de province ct de nation, autres que celui qu'ont les individus d'être libres et de defendre leurs propriétés contre les brigan et les conquerans: interêt prétendu de faire plus de commerce que les autres, de ne point acheter les marchandifes de l'étranger, de forcer l'étranger à confommer leurs productions et les ouvrages de leurs manufactures: interêt prétendu d'avoir 


\section{[ 97 ]}

d'avoir un territcire plus vafte, d'acquérir telle ou telle province, telle ou telle ille, tel ou tel village: interêt d'infpirer la crainte aux autres nations: interêt de l'emporter fur elles par la glöre des armes, par celle des arts et des fciences.

Quelques-uns de ces préjugés font fomentés en Europe, parce que la rivalité ancienne des nations et l'ambition des princes oblige tous les Etats à fe tenir armés pour fe défendre contre leurs voifins armés, et à regarder la force militaire comme l'objet principal du gouvernement. L'Amérique a le bonheur de ne pouvoir avoir d'ici ì bien longtems d'ennemi extérieur à craindre, fi elle ne fe divife elle même; ainfi elle peut et doit apprécier à leur jurte valeur ces prétendus interêts, ces fujets de difcorde qui feuls font ì redouter pour fa liberté. Avec le principe facré de la liberté du commerce regardé comme une fuite du droit de la proprieté, tous les prétendus interêts de commerce difparoiffent. Les prétendus interêts de poffeder plus ou moins de territoires s'évanouifient par le principe que le territoire n'appartient point aux nations, mais aux individus proprićtaires des terres; 


\section{[ $9^{8}$ ]}

que la queftion de favoir fi tel canton, tel village, doit appartenir à telle province, ̀̀. tel Etat ne doit point être décidée par le prétendu interêt de cette province ou de cet Etat, mais par celui qu'ont les habitans de tel canton ou de tel village de fe raffembler pour leurs affaires dans le lieu où il leur eft le plus commode d'aller; que cet interêt êtant mefuré par le plus ou moins de chemin qu'un homme peut faire loin de fon domicile pour traiter quelques affaires plus importantes fans trop nuire à fes affaires journalieres, devient une mefure naturclle et phyfique de l'étendue des jurifdictions ei des Etats, et établit entre tous un équilibre d'étendue et de forces, qui écarte tout danger d'inégalité, et toute prétention à la fupériorité.

L'interêt d'etre craint eft nul quand on ne demande rien à perfonne, et quand on eft dans une pofition où l'on ne peut être áttaqué par des forces confidérables avec quelque efpérance de fuccès.

La gloire des armes ne vaut pas le bonheur de vivre en paix. La gloire des arts, des fciences appartient à quiconque veut s'en failir; il y a dans ce genre à moiffonner pour 


\section{$\left[\begin{array}{ll}9 & 99\end{array}\right]$}

sout le monde; le champ des décourertes eft inépuifable, et tous profitent des découvertes des tous.

J'imagine que les Américains n'en font pas encore à fentir toutes ces verités, comme il faut qu'ils les fentent pour afiurer le bonheur de leur poftérité. Je ne blàme pas leurs chefs. Il a fallu pourvoir au befoin du mornent par une union telle quelle, contre un ennemi prélent et redou.table; on n'avoit pas le tems de fonger a corriger les vices des confitutions et de la compofition des différens etats. Mais ils doivent craindre de les éternifer, et s'occuper des moyens de rćunir les opinions et les interêts et de les ramener à des principes uniformes dans toutes leurs provinces.

Ils ont à cet égard de grands obftacles à vaincre.

En Canada, la confitution du clergé Romain, et l'exiftence d'un corps de nobleffe.

Dans la Nouvelle Angleterre, l'efprit encore fubfiftant du Puritanifme rigide, et soujours, dit on, un peu intolérant.

$\mathrm{O}_{2}$

Ding 


\section{[ 100$]$}

Dans la Penfylvanie, un très grand nombre de citoyens établiffant en principe religieux que la profeflion des armes eft illicite, et fe refufant par conféquent aux arrangemens néceffaires pour que le fondement de la force militaire de l'Etat, foit la réunion de la qualité de citoyen avec celle d'homme de guerre et de milicien; ce qui oblige à faire du métier de la guerre un métier de mercenaires.

Dans les colonies méridionales, une trop grande inégalité de fortunes, et fur tout le grand nombre d'eiclaves noirs dont l'efclavage eft incompatible avec une bonne confirction politique, et qui même en leur rendant la liberté embarrafferont encore cu formant deux nations dans le même Isat.

Dans toutes, les préjugés, l'attachement aix formes établies, l'habitude de certaines taxes, la crainte de celies qu'il faudroit y fubrituer, la vanité des colonies qui fe font cru les plus puiffantes, et un malheurcux commencement d'orgueil national. Je crois les Américains forcés à s'agrandir, non pas par la guerre, mais par la culture. S'ils 


\section{$\left[\begin{array}{ll}101 & 1\end{array}\right]$}

laiffoient derricre eux les déferts immonfés qui s'étendent jufqu'à la mer de l'Oucit il s'y etabliroit du mélange de leurs bannis, et des mauvais fujets échappés à la féverité des loix, avec les fauvages: des peuplades de brigands qui ravageroient l'Amérique, comme les barbares du nord ont ravagé l'empire Romain; de là un autre danger, la nécefitité de fe tenir en armes fur la frontiere et d'être dans un état de guerre continuelle. Les colonies voifines de la frontiere feroient en conféquence plus aguerries que les autres, et cette inégralité dans la force militaire feroit un aiguillon terrible pour l'ambition. Le remede à cette inégalité feroit d'entretenir une force militaire fubfiftante à laquelle toutes les provinces contribueroient en raifon de leur population; et les Américains qui ont encore toutes les craintes que doivent avoir les Anglois redoutent plus que toute chofe une armée permanente. Ils ont tort. Rien n'en plus aifé que de lier la confitution d'une armée permanente avec la milice, de façon que la milice en devienne meilleure, ct que la liberté n'en foit que plus affermie. Mais il crit mal aic de calmer fur cela leurs allarmes. 


\section{[ 100 ' ]}

Voila bien des difficultés, et peut-êtré les interêts fecrets des particuliers puiffans fe joindront-ils aux préjugés de la multitude pour arrêter les efforts des vrais fages et des vrais citoyens.

Il eft impoffble de ne pas faire des vœux pour que ce peuple parvienne à toute la profpérité dont il eft fuceptible. Il eft l'efpérance du genre humain. Il peut en devenir le modéle. Il doit prouver au monde, par le fait, que les hommes peuvent être libres et tranquilles, et peuvent fe pafer des chaines de toute efpece que les tyrans et les charlatans de toute robe ont prétendu leur impôfer fous le pretexte du bien public. Il doit donner l'exemple de la liberté politique, de la liberté religicufe, de la liberté du commerce et de l'induftrie. L'afyle qu'il ouvre à tous les opprimés de toutes les nations doit confoler la terre. La facilité d'en profiter pour fe dérober aux fuites d'un mauvais gouvernement forcera les gouvernemens d'être juftes, et de s'éclairer; le refte du monde ouvrira peu-à-peu les yeux fur le néant des illufions dont les politiques fe font bercés. Mais il faut pour cela que l'Amérique s'en garantife, et qu'elle ne redevienne pas 


$$
\text { [:03] }
$$

comme l'ont tant repeté vos técrivains minifteriels une image de notre Europe, un amas de puifances divifées, fe difputant des territoires ou des profits de commerce, et cimentant continuelloment l'efclavage des peuples par leur propre fang.

Tous les hommes eclairés, tous les amis de l'humanité devroient en ce moment réunir leurs lumieres et joindre leurs ićflexions à celles des fages Américains pour concourir au grand ouvrage de leur légiflation. Cela feroit digne de vous, Monfieur; je voudrois pouvoir échanffer votre zêle; et fi dans cette lettre je me fuis livré plus que je ne l'aurois dû peut-être à l'efiufion de mes propres idées, ce défir a été mon unique motif, et m'excufera à ce que j'efpere de l'ennui que je vous aurai caufé. Je voudrois que le fang qui a coulé, qui coulera encore dans cette querelle ne fût pas inutile au bonheur du genre humain.

Nos deux nations vont fe faire réciproquement bien du mal, probablement fans quaucune d'elles en retire un profit réel. L'accroifiement des dettes et des charges, 


\section{[ 104$]$}

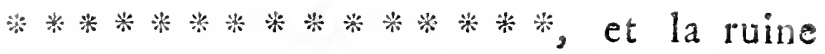
d'un grand nombre de citoyens en feront peut-être l'unique refultat. L'Angleterre m'en paroit plus près encore que la France. Si au lieu de cette guerre vous aviez pu vous exécuter de bonne grace dès le premier moment, s'il ĉtoit donné à la politique de faire d'avance ce qu'elle fera infailliblement forcée de faire plus tard, fi l'opinion nationale avoit pu permettre à votre gouvernement de prévenir les evenemens, en fuppofant qu'il les eut prévus, s'il eût pu confentir d'abord à l'indépendance de l'Amérique fans faire la guerre à perfonne, je crois fermement que votre nation n'auroit rien perdu à ce changement. Elle y perdra aujourd'hui ce qu'elle a dépenfé, ce qu'elle dépenfera encore; elle eprouvera une grande diminution pour quelque tems dans fon commerce, de grands boulever. femens intérieurs fi elle eft forcée à la banqueroute; et quoiqu'il arrive une grande diminution dans l'influence politique au dchors, mais ce dernier article eft d'une bien petite importance pour le bonheur réel d'un peuple, et je ne fuis point du tout de l'avis de l'Abbé Rainal dans votre épigraphe. Je ne crois point que ceci vous 


$$
\text { [ } 105]
$$

mene à devenir une nation mepriable, of vous jette dans l'efclavage.

Vos malheurs feront peut-être au cons traire l'effet d'une amputation nécefiaire; ils font peut-être le feul moyen de vous fauver de la cangrene du luxe et de la corruption. Si dans vos agitations vous pouviez corriger votre conflitution en rendant les elections annuelles, en repartifiant le droit de repréfentation d'une maniere plus égale et plus proportionnée aux interets des repréfentés, vous gagneriez peut-être autant que l'Amérique à cette révolution; car votre liberté vous refteroit, et vos autres pertes fe répareroient bien vîte avec elle et par elle.

Vous devez juger, Monfieur, par la franchife avec laquelle je m'ouvre à vous fur ces points délicats, de l'eftime que vous m'avéz infpirée, et de la fatisfaction que j'eprouve à penfer quil y a quelque reffemblance entre nos manieres de voir. Je compte bien que cette confidence n'eft que pour vous. Je vous prie même de ne point me répondre en détail par la polte, car votre réponfe feroit infailliblement ouverte dans nos burcaux 


$$
\text { [ } 106]
$$

de pofte, et l'on me trouveroit beaucoup trop ami de la liberté pour un miniftre, même pour un miniftre difgracié !

J'ai l'honneur d'etre, Monfieur, avec tcute la confideration poffible,

\section{Votre très humble,}

eł très obeiffant ferviteur,

\section{T URGOT.}

It is not cafy to do juftice in Englifh to many parts of the preceding letter. The following Iranflation of it will bowever, I bope, be found to be nearly correct; and I think myjelf greatly obliged to the Gentleman who bas been fo good as io favour me with it. 


\section{[ $: 07$ ]}

T R A N S L A

To Dr. P R I CE, London.

Paris, 2ad March, $177^{9}$.

S I R,

$M^{\text {R. FRANKLIN by your defire has }}$ put into my hands the laft edition of your Obfervations on Civil Liberty, Bc. for which I think myfelf doubly indebied to you. In the firft place, for the work itfelf, of which I have long known the value and read with great avidity, notwithftanding the multiplicity of my engagements, when it was firft publithed: And in the next place, for the politenefs you have fhewn in leaving out the imputation of woant of address, which you intermixed $\mathrm{P} 2$

with

* What is here faid refers to the following account of M. Turgot's adminiftration in the fecond tract on Civil Liberty and the $I V$ ar with Anerica, p. 150, \&c. is A new reign produced a new minifter of finace in 6. France, whofe name will be refpected by pofterity for "s a fet of meafures as new to the political world, as any " late difcoveries in the fyftem of nature have been to the s6 philogoplicial world-Doubtful in their oparation, as 


\section{[ 108$]$}

with the handrome thirgs you faid of me in your additional obfervations. I might have merited this imputation, if you had in view no other want of addre/s than incapacity to unravel the fprings of thofe intrigues that were employed againft me, by fome people who are much more expert in thefe matters than $I \mathrm{am}$, or ever thall be, or indeed ever defire to be: But I imagined you imputed to me a wont of addrefs which made my opi-

nions

" all untried meafures muft be, but diftinguifhed by " their tendency to lay a folid foundation for endleís "peace, induitry, and a general enjoyment of the gifts " of nature, arts and commerce-The edicts iffued dur" ing his adminiftration exhibit indeed a phanomenon of " the moft extraordinary kind. An abfolute King ren" dering a voluntary account to his fubjects, and inci"ting his people to think; a right which it has been the "bufinefs of all abfolute prinees and their mininfters to " extinguifh. - In thefe edicts the King declared in the " moft diftinct terms againft a bankruptcy, Sic. while " the minifter applied himfelf to increafe every public " refource by principles more liberal than France, or any "part of Europe, ever had in ferious contemplation."It is much to be regretted, that the oppofition he met " with and the intrigues of a court fhould have deprived " the world of thofe lights, which mutt have refulted from " the example of fuch an adminiftration." In this paffage I had, in the firft edition, mentioned improperly $\mathrm{Mr}$. 


\section{[ 109$]$}

nions grofsly clahs with the general opinions of my countrymen; and in that refpect I thought you neither did juftice to me nor to my country, where there is a degree of underftanding much fuperior to what you generally fuppofe in England, and where it is more eafy perhaps, than even with you, to bring back the public to hearken to reafon.

I have been led to judge thus by the infatuation of your people in the abird project of fubduing America, till the affair of Bur-

Turgot's want of aldlefs among the other caufes of his difmifion from power. This occafioned a letter from him to inform $m e$ of the true reafens of his difmifion, and begun that correfpondence, of which this letter is a part, and which continued till his death.- It may not be improper to add here, that his fucceflor was $\mathrm{Mr}$. Necker, author of the interefting Treatife on the Adminiftration of the Finances of France juft publithed; and that in the paffage juft quoted, the following notice is taken of this appointment.- " After a fhort in" terval, a nomination, in fome refpects" fill more ex" traordinary, tcok place in the Court of France. A " court, which a few years fince was diffinguifhed by its "bigotry and intolerance, has raifed a proteffant, the fub- I " jeet of a fmall but virtuous republic, to a decifive lead " in the regulation of its finances. It is to be prefumed " that fo fingular a preference will produce an equally "fingular exertion of integrity and talents." 


\section{[ 110$]$}

geyne began to open their eyes; and by t'.-e fyltem of monopoly and exclufion which has been recommended by all your writers on Commerce, (except Mr. Adam Smith and Dean Tucker); a fyftem which has been the true fource of your feparation from your Colonies. I have alfo been led to this opinion by all your controverfial writings upon the queftions which have occupied your attention there twenty years, and in which, till your obfervations appeared, I fcarce recollect to have read one that took up thefe queftions on their proper ground. I cannot conceive how a nation which has cultivated every branch of natural knowledge with fuch fuccers, thould have made to litile progrefs in the mort interefting of all fciences, that of the public good: A fience, in which the liberty of the Prefs, which the alone enjoys, ought to have given her a prodigious advantage over every other nation in Europe. Was it national pride which prevented you from profiting by this advantage? Or was it, becaufe you were not altogether in fo bad a condition as other nations, that you have impofed upon yourfelves in your fpeculations fo far as to be perfuadcd that your arrangements were comfleat? Is it party fpirit and a defire of being 


\section{[ IIt]}

fupported by popular opinion which has retarded your progrefs, by inducing your political writers to treat as vain Metaphyfics * all thofe fpeculations which aim at eftablining the rights and true interefts of nations and individuals upon fixed principles. How comes it that you are almont the firlt of the writers of your country, who has given a juft idea of liberty, and thewn the falfity of the notion fo frequently repeated by almof all Republican Writers, " that liberty con"fifts in being fubject only to the laws," as if a man could be free while oppreffed by an unjuft law. This would not be true, even if we could fuppofe that all the laws were the work of an aflembly of the whole nation; for certainly every individual has his rights, of which the nation cannot deprive him, except by violence and an unlawful ufe of the general power. Though you have attended to this truth and have explained yourfelf upon this head, perhaps it would have merited a more minute explanation, confidering how little attention is paid to it even by the mont zealous friends of liberty.

It is likewife extraordinary that it was not thought a trivial matter in England to affert

* See Mr. Burke's Letter to the Sheriffs of Brifol. 


\section{[ $\left.\begin{array}{lll}\text { II } & \text { L }\end{array}\right]$}

anden never can have a right to nation"-" that a governwhere furch a principle is admitted " can have "ndation but that of force, " which ir equally the foundation of robbery " and tyranny"- " and that the tyranny of " a people is the moft cruel and intolerable, "becaufe it leaves the feweft refources to the "opprefied."-A defpot is reftrained by a fenfe of his own intereft. He is checked by remorfe or by the public opinion. But the multitude never calculate. The multitude are never checked by remorfe, and will even afcribe to themfelves the higheft honour when they deferve only difgrace.

What a dreadful commentary on your book are the events which have lately befallen the Englifh nation ?--For fome montis they have been running headlong to ruin. - The fate of America is already decided-Behold her independent beyond recovery.-But will She be free and happy?-Can this new people, fo advantageouly placed for giving an example to the world of a conflitution under which man may cnjoy his rights, freely exercife all his facultics, and be governed only by nature, reafon and juftice-Can they form fuch a Conflitution?-Can they clablih it upon 


\section{[ II 3 ]}

a neverfailing foundation, and guard againft every fource of divifion and corruption which may gradually undermine and deftroy it?

I confers that I am not fatisfied with the Conftitutions which have hitherto been formed by the different States of America. It is with reafon that you reproach the State of Penfylvania with exacting a religious tent from thofe who become members of the body of Reprefentatives. There are much worfe tefts in the other States; and there is one (I believe the Jerfeys) which requires ( $\left.\omega^{2}\right)$ a declaration of faith in the Divinity of Jefus Chrift.-I obferve that by moft of them the cuftoms of England are imitated, without any particular motive. Inftead of collecting all authority into one center, that of the nation, they have eftablithed different bodies; a body of reprefentatives, a council, and a Governour, becaure there is in England a Houfe of Commons, a Houre of Lords, and a King.- They endeavour to balance thefe different powers,

$(t)$ It is the Confitution of Delivare that impofes the teft here meant. That of the fer feys, with a noble li-1 berality, orders that there thall never in that Province be any eftablifhment of any one religious feet in preference to another, and that ail Proteftants of all perfuafions fhall enjoy equal rights and privileges. 


\section{[II4]}

as if this equiibrium, which in England may be a neceffary check to the enormous infuence of royalty, could be of any ufe in Republics founded upon the equality of all the Citizens; and as if eitablihing different orders of men, was not a fource of divifions and difputes. In attempting to prevent imaginary dangers they create real ones; and in their desire to have nothing to feas: from the clergy, they unite them more clofely by one common profeription. By excluding them from the right of being elected into public offices they become a body diftinct from the State. Wherefore Thould a Citizen, whohas the fame intereft withothers in the common defence of liberty and property, be excluded from contributing to it his virtue and knowledge? Is it becaure he is of a profeftion which requires knowledge and virtue? The clergy are only dangerous when they exift as a diftinct body in the State; and think themfelves poffefled of feparate rights and interents and a religion eftablinhed by law, as if fome men had a right to regulate the confciences of other men, or could have an intereft in doing this; as if an individual could facrifice to civil focicty opinions on which he thinks his 


\section{$[\mathrm{II} j$ j}

eternal Givation depends; as if, in Gort. mankind were to be faved or damed in communities-Where true toleration, (that is, where the abfolute incompetency of civil government in matters of con?cience, is eftabli(hed); there the clergymon, when admitted into the national affembly, becomes a fimple citizen; but when excluded, he becomes an ecclisfuftic.

I do not think they are fuficiently careful to reduce the kind of bufinefs with which the government of each State is charged, within the narrowent limits poffible; nor to feparate the objecrs of legillation from thofe of the general adminiftration, or from thofe of a local and particular adminiftration; nor to inftitute local permanent affemblies, which by difcharging almont all the functions in the detail of government, make it unnecefiary for the general afiemblies to attend to theie things, and thereby deprive the members of the general afiemblies of every means, and perhaps every defire, of abufing a power which can only be applied to general objects, and which, confequentIy, mut be free from the infuence of the little pafions by which men ufually are agitated.

$$
2: \quad \text { I do }
$$




\section{[ I16 ]}

I do not find that they attend to the great diftinction (the only one which is founded in nature between two claffes of men), between landholders, and thofe who are not landholders; to their interefts, and of courfe to their different rights refpecting legillation, the adminiftration of juftice and police, their contributions to the public expence, and employment.

No fixed principle of taxation is eftablifhed. They fuppofe that each State may $\operatorname{tax}$ itfelf according to its own fancy, by eftablifhing either perfonal taxes, or taxes on confumption and importation; that is, that each State may affume to itfelf an intereft contrary to the intereft of the other States.

They alfo every where fuppofe that they have a right to regulate commerce. They cven delegate authority to executive bodies, and to Governors, to prohibit the exportation of certain commodities on certain occafions. So far are they from being fenfible that the right to an entire liberty in commerce is the confequence of the right of property. So much are they ftill involved in the mift of European illufions.

In the general union of the States I do not obferve a coalition, a fufion of all the 


\section{[ III ]}

parts to form one homogeneous body. It is only a jumble of communities too difcordant, and which retain a confant tendency to feparation, owing to the diverfity in their laws, cuftoms and opinions; to the inequality in their prefent ftrength; but ftill more, to the inequality in their advances to greater frength. It is only a copy of the Dutch republic, with this difference, that the Dutch republic had nothing to fear, as the American republic has, from the future poffible increafe of any one of the Provinces. - All this edifice has been hitherto fupported upon the erroneous foundation of the molt ancient and vulgar policy; upon the prejudice that $\mathrm{Na-}$ tions and States, as fuch, may have an intereft diftinct from the intereft which individuals have to be free, and to defend their property againt the attacks of robbers and conquerors: An intereft, in carrying on a more extenfive commerce than other States, in not purchafing foreign merchandize, and compelling foreigners to confume their produce and manufactures: An intereft in poffefling more extenfive territories, and acquiring fuch and fuch a province, ifland or village: An intereftin infpiring other nations with awe, and gaining a 


$$
\text { [ } 118 \text { ] }
$$

fuperiority over them in the glory of $\mathrm{arts}_{3}$ fciences, and arms.

Some of thefe prejudices are fomented in Europe, from the ancient rivalnip of nations and the ambition of Princes, which compel every State to keep up an armed force to defend itfelf againft the attack of neighbours in arms, and to look upon a military force as the principal object of government. America is likely in no long time to enjoy the happinefs of having no external enemy to dread, provided the is not divided within herfelf. She ought, therefore, to eftimate properly thore pretended interefts and caufes of difcord which alone are likely to be formidable to her liberty. On that facred principle, " liberty of commerce " confidered as a natural right flowing from " the poffefion of property," all the pretended interefts of commerce muft vanih.The fuppofed intereft in poffefling more or lefs territory difappear on this principle, " that a territory does not belong to na" tions, but to the individuals who are pro" prietors of the lands." The queftion, whether fuch a canton or fuch a village belongs to fuch a Province or fuch a State, ought not to be determined by the interent in it pretended by that Province or that 


\section{[ I 19$]$}

State; but by the intereft the inhabitants of the canton or village have $i$ a affembling for tranfacting their affairs in the place moft convenient for them. This intereft, meafured by the greater or lefs diftance that a man can go from his home to attend to important affairs without injuring his private concerns, forms a natural boundary to the jurifdiction of States, and eftablihes an equipoife * of extent and frength between them, which muft remove every danger of inequality, and every pretence to fuperionity.

There can be no intereft in being feared when nothing can be demanded, and when men aie in a fituation not to be attacked by a confiderable force with any hope of fuccers.

The glory of arms is nothing to thofe who enjoy the happinefs of living in peace.

The glory of arts and fciences belongs to every man who can acquire it. There is

* This feems to be a particular of much confequence. The great inequality now exifting, and which is likely to increafe, between the different States, is a very unfavourable circumftance; and the embaraffinent and danger to which it expoles the union ought to be guarded again?t as far as poffible in laying out future Ştates. 


\section{[ I 20 ]}

here ample fcope. The field of difcovery is boundlefs; and all profit by the difcoveries of all.

I imagine that the Americans are not as fenfible of thefe truths, as they ought to be, in order to fecure the happinefs of their pofterity. I do not blame their leaders. It was neceffary to provide for the neceffities of the moment, by fuch an union as they could form againft a prefent and moft formidable enemy. They have not leifure to confider how the errors of the different conftitutions and States may be corrected; but they ought to be afraid of perpetuating thefe errors, and to endeavour by all means to reconcile the opinions and interefts of the different provinces, and to unite them by bringing them to one uniform fet of principles.

To accomplith this they have great obftacles to furmount.

In Canada, an order of Roman Catholic Clergy, and a body of Nobles.

In New England, a rigid puritanical fpirit which has been always fomewhat intolerant *.

1 * This has been once true of the inhabitants of NewEngland, but it is not fo now. See p. 47 . 


\section{[ I 21$]$}

In Penfylvania, a very great number of inhabitants laying it down as a religious principle, that the profefion of arms is unlawful, and refuring to join in the arrangements neceflary to eftabiin the military force of the State, by uniting the character of the Citizen with that of the Soldier and Miiitiaman, in confequence of which the bufinefs of war is made to be the bufinefs of merccnaries.

In the Southern Colonies, an inequality of fortune too great; and what is worfe, a great number of Blacks, whofe Davery is incompatible with a good political conftitution; and who, if emancipated, would occafion great embarrafiement by forming two difinct people in one State.

In all of them, various prejudices, an attachment to eftablinhed forms, a habit of paying certain taxes, and a dread of thofe which muft be fubltituted for them; a vanity in thofe colonies which think themfelves mort powerful; and a wretched beginning of national pride. I imagine that the Americans mut aggrandize themfelves not by war, but by agriculture. If they negleet the immenfe defarts which are at their backs, and which extend all the way 


\section{[ 122$]$}

tu the wefern fea, their exiles and fugitives from the feverity of the laws, will unite with the Savages, and fettle that part of the country; the confequence of which will be that bodies of Banditti will ravage America, as the Barbarians of the North ravaged the Roman Empire, and fubject the States to the neceflity of keeping the frontiers always guarded, and remaining in a State of continual war. The Colonies next to the frontier will of courfe be better difciplined than the reft; and this inequality of military force will prove a dreadful incentive to ambition. The remedy for this inequality would be to keep up a fanding army, to which every State fhould contribute in proportion to its population; but the Americans, who have the fears that the Englim ought to have, dread nothing fo much as a ftanding army. In this they are wrong. There is nothing more eafy than to combine a ftanding army with a militia, fo as to improve the militia, and gain additional fecurity for liberty. But it is no eafy matter to calm their apprehenfions on that head.

Here are a number of difficulties; and perhaps the private interents of powerful individuals 


$$
\text { [ I } \left.\begin{array}{ll}
2 & 3
\end{array}\right]
$$

individuals will unite with the prejudices of the multitude, to check the efforts of true Philofophers and good Citizens.

It is impoffible not to with ardently that this people may attain to all the profperity of which they are capable. They are the bope of the world. They may become a model to it. They may prove by fact that men can be free and yet tranquil; and that it is in their power to reicue themfelves from the chains in which tyrants and knaves of all defcriptions have prefumed to bind them under the pretence of the public good. They may exhibit an example of political liberty, of religious liberty, of commerical liberty, and of induftry. The Afylum they open to the oppreffed of ail nations fhould confole the earth. The eafe with which the injured may efcape from oppreffive governments, will compel Princes to become juft and cautious; and the reft of the world will gradually open their eyes upon the empty illufions with which they have been hitherto cheated by politicians. But for this purpofe America muft preferve berfelf from thefe illufions; and take care to avoid being what your minifterial writers are freR 2 quently 


$$
\text { [ } 324 \text { ] }
$$

quenty faying she will be-an image of our 1 Eurepe-a mars of divided powers contending for territory and commerce, and continually cementing the flavery of the people with their own blood.

All enlightened men-All the friends of humanity ought at this time to unite their lights to thofe of the American fages, and to affift them in the great work of legiflation. This, frr, would be a work worthy of you. I win it was in my power to animate your zeal in this inftance. If $I$ have in this letter indulged too free an effufion of my fentiments, this has been my only motive; and is will, I hope, induce you to pardon me for tiring you. I wih indeed that the blood which has been fpilt, and which will contiune for fome time to be fpilt in this conteft, may not be without its we to the homan race.

Our two nakions are about doing much harm to each other, and probably without the profpect to either of any real advantage. An increafe of debts and public burthens, (perhaps a national bankruptcy), and the ruin of a great number of individuals, will prove the refult. England feems to me to be more likely to fuffer by thefe evils, and much nearer to them, than France. 


\section{[ 125$]$}

-If infead of going to war, you had at the commencement of your difputes encavoured to retreat with a good grace; if your Statefmen had then confented to make thofe concefions, which they will infallibly be obliged to make at lan; if the national opinion would have permitted your government to anticipate events which might have been forefeen; if, in fhort, you had immediately yielded to the independence of America without entering into any hoftilities; I am firmly perfuaded your nation would have loft nothing.-But you will nowo lofe what you have already expended, and what you are ftill to expend; you will experience a great diminution of your commerce for fome time, and great interior commotions, if driven to a bankruptcy; and, at any rate, a great diminution of weight in foreign politics. But this laft circumftance I think of little confequence to the real happinefs of a people; for I cannot agree with the Abbe Raynal in your motto*.

I do

* This refers to the following words (taken from Mr. Juftamond's tranflation of the Abbe Raynal's Hitory of the European Settlements) in the Title-page to the Second Tract on Civil Liberty_-" Should the morals " of the Englifh be perverted by luxury-hould they 


$$
\text { [ } 125]
$$

I do not believe all this will make you a contemptible nation or throw you into favery.-On the contrary; your misfortunes may have the effeci of a neceffary amputation. They are perhaps the only means of faving you from the gangrene of luxury and corruption. And if they hould terminate in the amendment of your conftitution, by reftoring annual elections, and diftributing the right of fuffrages for reprefentation fo as to render it more equal and better proportioned to the interefts of the reprefented, you will perhaps gain as much as America by this revolution; for you will preferve your liberty, and with your liberty, and by means of it, all your other lofles will be fpeedily repaired.

By the freedom with which I have opened myfelf to you, fir, upon thefe delicate points, you will judge of the efteem with which you have infpired me; and the fatisfaction I feel in thinking there is fome re-

" lore their colonies by refraining them, \&c. they will "be enfaved. They will become infignificant and " contemptible; and Europe will not be able to hew " the world one nation in which the can pride herfelf." 


\title{
[ 127$]$
}

femblance between our fentiments and views. I depend on your" confining this confidence to yourfelf. I even beg that you will not be particular in anfwering me by the Poft, for your letter will certainly be opened at out Poft-Offices, and I thall be found much too great a friend to liberty for a minifter, even though a difcarded minifer.

I have the honour to be with all porfible refpect,

\author{
Sir, \\ Your moft humble, \\ and moit obedient Servant, \\ T UR GO T.
}

* In compliance with Mr. Turgot's defire, this letter was kept private during his life. Since his death I have thought the publication of it a duty which I owe to his memory, as well as to the United States and the world. I can add, with much fatisfaction, that my venerable friend and the excellent Philofopher and Satefman whofe name introduces this letter; and alfo, that fome intimate friends of Mr. Turgot's, who , have been confulted on this fubject, concus with me in this fentiment.

\section{Note omitted in Page 52.}

The imperfection of real knowledge may often produce unreafonabie incredulity. - - Had the beft Philofophers been told a few years ago, " that there exifed fintes which " had the conmand of ligbtening, and which ufed it to " kill their prey," they would have fiouted the ufoumațion as ablurd and ridiculous. 



\title{
A $P \quad P \quad E \quad N \quad D$ I $X$,
}

\author{
CONTAINING
}

A Translation from the Freich of

\section{THE TESTAMENT \\ $\mathrm{OF}$}

\begin{abstract}
M. FORTUNÉ RICARD,
TeAcher of ARITHMEtic at D-D.
\end{abstract}

Read and publifned at the Court of Barnivick of that

Town, the 19 th of AUGust, 1784 .

PRINTED IN M.DCC.LXXXV. 



\section{ADVERTISEMENT.}

$T^{H} H$ E following Teftament was lately publifsed in France, and conveyed to me by $D_{i}$. Franklin. It exempliges, with an inftrustive pleafantry and great force, the account in page 10, ESc. of the porvers of Compound Intereft or a Sinking Fund, and the infes to wohich they may be applied for the benefit of nations and of pollerity. For this reafon I bere offer to the public the following tranlation of it, not doubting but I frall be exculied if the turn of humour in it renders it a compofition of a nature not perfectly fintable to the other parts of this painplobt. 



\section{[ 133 ]}

'T II E

\section{TESTAMENT, $B$}

$I^{N}$ the name of God, I Fortune Ricord, Teacher this my laft Will as follows patron, do make

["The Fxecutors, who have caufed this Wil? "to be printed in order to fulfil the intentions " of the late M. Fortune Ricard, do not think is " neceffary to publifh thofe particular bequelts " which concern only his own family. - Aiter " having difpofed of his patrimony among them " with wiflom, he proceeds in the following man"ner."]

It remains now for me to declare my intentions with regard to the promife of 500 lives*, fubicribed on my bihalf by M. P. banker

$$
\% 226.45 .6 \%
$$




\section{[ 34 ]}

banker of this town. This fum proceeded originally from a prefent which was made me by Prof per Ricard, my much honoured grandfather, when I entered the eighth year of my age. At that age he had taught me the principles of writing and calculation. After having fhewn me that a capital, with its accumulating intereft at five per cent. would amount at the end of 100 years to more than 131 times the original fun ${ }^{*}$, and feeing that I liftened to this lecture with the greatef attention, he took 24 livres $f$ out of his pocket, and addrefied me with an enthufiafm which is ftill prefent to my nind-_" My child, faid he, remember " while thou liveft, that with ceconomy and cal"culation nothing is impofible for man. Here "are 24 liveres which I give thee. Take them to " a merchent in our neighbourbood, who will "place them in trade out of regard to me. "Every year thou fhalt add the intereft to the " principal. At thy death thou halt employ the "produce in good works for the repole of thy "foul and my own."-I have executed this order with fidelity, and in the courfe of my life I have planned many projeds for employing this money. Having reached the 7 in year of my age, it amounts to 500 liveres; but as I mutt fome time or other fet bounds to mylelf, I now defire that it may be divided into five portions of 100 livres to each; to which the interefts thall be annually added, and the accumulated fums thall be fucceffively applied to the following ures.

I. In a burded years the finf fum of Ioo livres will amount to more than 13,100 livres $\$,(5822 l$. $)$.

From

\footnotetext{
* Sce table if annexed to this Will.

t Nenty a guinea.

\# Four pounds nine finillings.

S Sec tible t find at.
} 


\section{[ 135 ]}

From this fum a prize of 4000 livres fhall be given for the belt theological difiertation, in prove the lawfulnefs of putting out money to intereft. Three medals, of 600 lives each, thall alio be given for the three differtions which thall be adjudged the next in nerit to the prize-diveration. The remainder of the 13,100 livres thall be expended in printing the prize differtation and extracts from the others. Copies of the fe thall be fent, gratis, to all the bilhops, clergy, and confeffors of the kingdom. I hat intended to have fent them alfo into forcign countries; but I ob. ferve that all the univerficies of the chriftian world, excepting thofe of France, have folemnly reconnized the lawfulnets of putting money to intereft"; and that it continues neceffury only in this kingdom to explain a queftion in morals do interelt. ing to the welfare of the State.

2. After two bundred years a feccial fum of 100 livres, amounting, with its accunbulated intereft, to more than 1,700,000 lives,$+(756,500 \%)$ thall be employed in eltablithing a perpetual fund for fourfcore prizes of rooo livres each, to be diftributed annually by the different academies of the kingdom, as follows:-Fifteen prizes for the molt diftinguifhed virtwous actions-fifteen for works of fcience and literature-ten for folutions of quettions in arit!metic and calculation-ten for fuch new procefies in agriculture as thall produce the beft crops-ten for matier-pieces in the fine arts-

and

* See the approbations of the Univerfitics of Alcala, Salamanca, Ingolfadt, Fribourg in Brifgaw, Mayence, Cologne and 'ireves, printed at the ent of a qrictife upon Ujury and Intere,t. Lyos. Brumel-Ponthis, 1776 , in $12 \mathrm{mo}$. The firlt five of thefe approbitions have been depofited in the archives of the confulhip of the som of Lyons.

t See table ad and th. 


\section{[ 135$]$}

and ten to encourage races and other exercifes proper to difplay the force and agility of the body, and to reftore amongt us a talte for the gymalium which was in fuch great efteem ainong the Gretks, and which-formerly made fo many heroes.

After three bundied years, from another fum of 100 livres, increafed in that time to more than two hundred and twenty-fix millions, (10,057,000l.) there nall be appropriated 196 millions towards eftablithing, in the moft confrderable places in France, 500 patriotic banks for lending money without intereft; the largeft of which thall have a fund of ten millions of livres, and the fmallelt a fund of 100,000 livres. 'Thefe banks thall be managed by a committee of the mot upright citizens in each place, and the money flall be employed in loans to fuccour the unfortunate, or advanced towards promocing agriculcure, trade, and induftry. The remaining ibirty millions thall be expended in founding twelve mufeums in the cities of Paris, Lyons, Rouen, Bourdeaux, Rennes, Line, Nancy, Pours, Dijon, Thouloule, Aix, and Grenoble. Each of thele mufenims thall be placed at the moft agreeable end of the city. Five hundred thoufand livres fhall be expended upon each building, and in the purchate of grounds which thall belong to them, and be laid out into botanical and fruit gardens, and alfo into kitchen gardens and extenifve walks. To each mufeum thall be annexed an income of 100,000 livres; and there fhall be lodged and boarded in it forty literary men and artits of fuperior merit, who, at the time of meals thall be divided inio four tables, that their repalts may be chearful without being too 
noify. Each mufeum fhall be provided with lis Secretaries, a defigner and engraver, and four carriages. There fhall be alfo a hall for concerts, a theatre, a chymical laboratory, a cabinet of natural hiftory, a hall for experimental philofophy, and a grand gallery for a common library. A bundred thoufand livres thall be expended on a feparate library for each of thefe eitablifhments. The fame fum thall be employed in proviciing them with feparate cabinets of natural hiftory and with philofophical inftruments. And 10,000 livres thall be referved annually for keeping up and increafing thefe cabinets and philofophical inftruments.*

The libraries thall always be open to the pub. lic. Twenty members of the nufeum hall be engaged in giving public and gratuitous courfes of lectures upon the foreign languares, and upon all the arts and fciences. The other twenty forall be engaged in fuch other employments as may be moft uleful. No one hall be admitted a member till he has previounly given proof, not of his rank, defcent, or nobility, but of his morals, and of his never having dihonoured his pen by writing againft + religion and government, or by fatirifing any member of the community. On being admitted he fhall make oath, "That he will " prefer virtue, truth, and his country to every " thing; and the general good of literature to " his own fame." The works of the nembers of the mufeum thall be printed at the expence of the T

cilia-

\section{* See table 5 th.}

+ No good men will ever write againt reigion and government. On the contrary; they will do all they can to render them greaser blefings, by fpreading jut notions of them, and clearing them from thote abules and cciruptions by which ufurpers and hypositas have made thos the means of enttaving and debafing mankind. 


\section{[ $\mathrm{I}_{3} 8$ ]}

eftablifhment, and when thofe expences are reim. burfed, the profits hall belong to the authors.

4. After four bundred years the fourth fum of 100 livres, amounting, with intereft, to near 30,000 millions, $(1,330,000,000 l$. ) thall be employed in building 100 towns, each containing 150,000 fouls $*$, in the inoft agreeable fituations which can be found in France. The means of peopling thefe towns, of governing and making them flourioh, are explained in a memorial annexed to this will $t$. In a hort time there will refult from hence an addition of 15 millions of inhabitants to the kingdom, and its confumption will be doubled, for which fervice I hope the ceconomifts will think themfelves obliged to me.

I am fenfible that all the fpecie in Europe is not equal to thefe 30,000 millions, and that it will be impoffible to make provifion in money for fuch immenfe fums. For this realon I leave it to the difcretion of my executors to exchange cafh at convenient feafons for landed and other real pofferfions. The revenue arifing from thofe poffefions fhall either be laid out in cafh, or realized by surther purchales, fo that my bequefts may be fulfilled in their due time without any difficulty:

I am convinced, by the moft accurate calculations, that my arrangements inftead of clogging will give activity to the circulation of fpecie. Laying out the money I have ordered in the pur-

chafe

* See table 6th.

+ The Executors have not yct determined whether they fhall publifh this Memorial, which is very copious, and contains fome ideas that may claim originality. The more inmediate concerns of their executorhip have not yet afforded them time for examining the whole of it. Beftdes, there can be no necefity of hurrying the publication, inafmuch a: the towns of which it treats are not to be built till the ent of four centuries. 


\section{[ 139 ]}

chafe of eftates, will foon increafe their value; and when thele accumulating riches fhall have fo produced their effect as that there can no longer be found in France a landholder who will fell his eftate, purchafes mut be fought for among the neighbouring nations.

5. Finally, with regard to the lat fum of 100 livres, amounting nearly, by the accumulation of five bundred years, to four millions of millions of livres, * it hall be difpoled of as follows.

Six thoufand millions fhall be appropriated towards paying the national debt of France, upon condition that the Kings, our good lords and mafters, thall be entreated to order the comptrollers general of the finances to undergo in future an examination in arithmetic + before they enter upon their office.

Twelve thoufand millions thall likewife be enployed in paying the public debts of England.It may be feen that I reckon that both thoie national debts will be doubled in this period; not that I have any doubts of the talents of certain minifters to increafe them much more, but their operations in this way are oppofed by an infinity of circumftances which lead me to prefume that thofe debts cannot be more than doubled. Befides, if they amount to a few thoufands of millions more, I declare that it is my intention that they fhould be entirely paid off, and that a project fo laudable thould not remain unexecuted $\mathrm{T} 2$ for

* 1,6 thoufands of millions fterling. - See tables $\approx d$ and 7 th.

+ There have been, it is faid, even in ENGLAND Lords of the Admiralty who could not count, and Chancellors of the Exchequer who could not read figures. 
Erot a trifie more or lefs. I beg that the Englifh would not refule this flight mark of the remembrance of a man, who was indeed born a Frenchman, but who fincerely efteemed their nation, and always was a particular admirer of that magnificent work which Newton, their countryman, has entitled Univerfal Aritbmetic. I earnettly defire that, as an acknowledgment for this legacy, the Englin nation will conlent to call the French their neigbbours* and not their natural enemies; that they be affured that nature never made man an enemy to man; and that national hatreds, commercial prohibitions, and, above all, wars conitantly produce a monftrous error in calculations. Put $I$ dare not, in this inftance, require any thing. We mult hope for all we defire from time; and when we have the happinefs of rendering a fervice, we muf not deftroy its value by annexing conditions to it which may encumber thofe whom we with to ferve.

Thirty thoufand millions thall be formed into a fund for producing an annual revenue of 15 hundred millions to be divided in times of peace among all the powers of Europe. In time of war the thare of the aggreffor or aggreffors fhall be given to thole who have been attacked unjuftly, in order to engage fovereigns, if poflible, to reflect a little before they commence unjult hoftilities. This revenue thall be diftributed among the different nations in proportion to their population. Every ten years an exact numeration

* The parable of the good Samaritan directs every man to look upon every man as his neighbour, without regarding his country or religion. M. Ricard appears to have attended to this divine inftruction. But Englifmen probably forget it, when, in their public devotions, they pray that God yould abate tbe pridic and afluge the malice of their enemies. 


\section{[ I I I ]}

tion thall be taken with a view to this difribution, which thall be made by a diet compofed of defuties from all the different nations; but I direet that a larece proportion fhall be distributed to thofe fovereigns who Sall apply for it and appear to defire it with no other view than to encourage population among their fubjects.

1 leave to the wifdom of my executors the care of extending the benefits of this bequent to the other parts of the world; and if, by this means, they fhould hope ro fucceed in extinguilhing throughout the world the ablurd and barbarous rage of war, I willingly confent that they appropriate for this purpofe the further fum of one hundred thoufand millions. I wifh that fix thoufand millions may be offered to his Majelty, the King of France; namely, a tboufand millions to fuperfede the necefity of lotteries, a fort of tax impofed upon wicked men which infallibly renders them a great deal more wicked; a thoufand millions to buy in all ufelefs offices which are attended with the fad inconvenience of perfuading many perfons that it is a fufficient dilcharge of their duty to their country to occupy an office withou functions, and that an honour may be derived from bearing a fenfelets title; a thoufand milliors to buy in offices which, on the contrary, are too important to be left expofed to the danger of venality; a thoufand millions to purchate a domain for his Majefty worthy of his crown, and fufficient for the expences oif his court, fo that the nation may clearly perceive that the taxes impofed upon them are applicable only to the expenditures of the Atatc. The remaining two thoufand millions fhall form a find, whofe annual produce fhall be employed by his Majefty in penfions and gratuities. By thefe means, if fometimes thofe favours

hould 


\section{[ 142$]$}

fhould be conferred upon intriguing and undeferving perfons, the nation will have no caufe to complain of the improper ufe of money drawn from taxes and the labours of the hurbandman.

I appoint a thoufand millions towards adding a thoufand livres to the fettled income of all the clergy in the kingdom, and 600 livres to that of their vicars, upon condition that they no longer demand fees for faying mafles. I had. alio tome thoughts of propofing to them the fupprefion of fees for baptifms, marriages, and burials; but I have confidered thofe functions to be of a civil as well as religious nature; and that on this account the clergy may, without impropriety, be allowed to receive a pay which is, in fact, more moderate than would be required by any other public officers in their places. Befides, this pay, perhaps, renders the fervice more exact, more fpeedy on their part, and lefs irkfome to the delicacy of fome of thofe who receive it.

I appoint two thoufand millions towards forming an income of ten livres a month to all the children which fhall be born in the kingdom till they are three years of age; and I defire this legacy to be increafed to thirty livres a month to thofe children which thall be nurfed by their own mothers. I do not except even the children of the rich; on the contrary, I invite rich parents to accept this donation without reluctance, as an honorary prize awarded to parernity and the cares of maternal love. They may, if they pleafe, apply it to acts of charity and benevolence.

I appoint four thoufand millions towards purchafing the wafte lands of the kingdom. There 


\section{[. 143 ]}

Thefe thall be divided into 500 thotifand little farms or tenements of four or live acres each. on which fhall be ereeted as many commodious cottages. Theie 500 thoufand farms thatl be given as freeholds to an equal number of married peafants, chofen in each parifh by a veftry compofed of ten of the moft aged inhabitants. The poffefiors of thefe freekolds thall be obliged to make them their only refidence, to cultivare them with their own hands and thofe of their $\mathrm{fa}$ milies, and to report every year the improvements of them which they have made. Thefe freebolds fhall be hereditary, but only upon condition that they fhall neither be divided, nor any two of them engroffed by one perfon. When a freeholder dies without leaving behind him either wife, children, brothers, fifters, nephews, or nieces, who have lived and laboured with him for three years prior to his deceafe, the freehold thall be declared vacant, and given anew by the veitry of the parith to that peafint who thall appear to deferve it beit.

I defire that two thoufand millions be laid out in purchafing all the manors of which there fnall be fellers, and that the vaffals thereon be for ever afterwards exempted from all fervitude and fealty.

Six thoufand millions flall be employed in founding houfes of education in all the country parifhes, agreeable to the plan of the author of a work entitled, Patriotic Viewes refpecting the Education of the People. If in executing this plan of a man of genius and an excellent citizen it thould appear to want fome little amendments and alterations, I direct that they fhall be adopted.

$I$ appoint 20,000 millions towards eredting in the kingtiom 40,000 houfes of labour, or public work- 


\section{[ 144 ]}

work-houfes; to each of which thall be appropriated from 10,000 to 50,000 livres annual income. Every man and woman thall have a right to offer themfelves at any time to be maintained and employed in them. I chufe to fay nothing of any other particulars in the government and management of thefe houfes; hoping that the ideas which begin to be formed concerning eftablithments of this kind will be perfecter betore the period fixed for thefe thall arrive; and that it will at length be univerfally ackinowledged, that though it is dangerous and Ioolith to give alms in money to a ftrong beggar, yet that fociety has no right to deprive him of his liberty and inflict punifhments upon him, while it does not hold out to him any other means of fubitience, or at leaft point out to him a method of difcovering what means he is capable of ufing.

I intreat the managers of thete public workhoufes to give the greateft encouragement to fuch trades as can be performed by women. 'This fex, fo dear to all fenfible minds, has been neglected or opprefied by all our inititutions. - Seductions of all kinds feem to confipire againft their virtue - Neceffity precipitates them involuntarily into an abyis of infamy and mifery. -The low price which is fet upon the labour of women is out of all proportion to the inferiority of their bodily Atrength. Let the public workhoufes fet the example of paying them better.

There are in France many houles of correction where the mifconduet of women is feverely punifhed, but where in reality it is only fufpended, mere confinement having no tendency to eradicate vice. Why fhould there not be one eftablimment where a young woman, conquered by temptation and on the brink of defpair, might prefent 


\section{[ 145$]$}

prefent herfelf, and fay - "Vice offers me goid: "I only afk for labour and bread. In compafion " to my remorfe afift and ftrengthen me. Open " an afylum for me where I may weep without " being feen, expiate thofe fauls which purfue " and overwhelm me, and recover a thadow of "peace."-Such an infitution exifts no whereI appint, therefore, a thoufand millions towards eftablihing one.

The fnares which are laid by vice for women without fortunes, would make fewer victims if more affiftance was given them. We have an infinity of eftablifhments for perfons in the higher ranks of life which do honour to the generofity of our forefathers. Why have we none for this purpofe?-I delire, therefore, that two thouland millions be employed in eftablithing in the kingdom a kundred hofpitals, which thall be called Hospitals of Angels. There firall be admitted into each a hundred females of the age of feven or eight years, and of the moft engaging forms. They fhall receive the moft perfect education in regard to morals, ufeful knowledge, and agreeable accomplinments. At the age of eighteen they may quit the hofpital in order to be married; at which period they fhall each be paid a portion of 40,000 livres. I mention this moderate fum becaufe it is my wifh that they be neither reproached for want of fortune, nor cfpoufed from intereft. An annulal income of 2000 livres fhall be given alfo to their parents. *** Except once in the year at a folemn and fplendid proceffion, they thall rarely appear in public, but hall be conftantly employed in their afylum in learning all that can ronder them one day excellent wives and mothers.

In order to fit them, in particular, for domefic aconomy, I defire that after they have been taught the moft accurate ideas of expences of all kinds, 


\section{[ 346 ]}

queftions be propofed to them from time to time to which they hall be obliged to give anfwers by word of mouth, and alfo in writing; as for example-" If you had fuch or fuch an income, un" der fuch or fuch circumftances, how much " would you appropriate to your table, your " houfe-rent, your maintenance, and the educa" tion of your children? How many fervants " would you keep? How much would you re" ferve for ficknets and unforcfeen expences? "How much would you confecrate to the relief " of the unfortunate and the public good?-If "your income depended either entirely or in part "upon a tranfient advantage or a place which was " not affured to you, how much would you expend " annually? What fum would you referve for form“ ing a capital?" \& cc. \& cc. Prizes publicly given to the beft anfwers to queftion's of rhis kind would conftiture, in my opinion, an exercife equally engaging and more ufeful than the little comedies and novels with which young perfons in the higher ftations are generally entertained.

The honours conferred upon great men have always appeared to me the moft effectual means of producing great men. I appoint, therefore, a thoufand millions towards ftriking medals, and placing in the halls of all towns, or in any other convenient places, fratues and butts in honour of fuch great men as thall hereatter rife up. I defire furcher that there honours be not paid them till ten years after their deceale; and that they be decreed and proportioned by a tribunal compofed of fuch upright, enlightened, and worthy citizens, as fhall be moft likely not to be dazzled by fatie vircues.-It has been once reckoned, that founding hofpitals for the fick is one of the beft public fervices. For fome years a conviction has 


\section{[ 147 ]}

been gaining ground, that breathing the pefts. lential air of hofpitals doubles the danger of difeales; and that on this and orher accounts they probably deftroy more lives than they face. I defire, therefore, that 10,000 millions be emplayed in eftablifhing in each parifh of the kingdiom boufes of bealib, in which thall be maintained a phyfician, a furgeon, and a convenient number of filters of charity and nurfes. Thefe houtes fhall fupply the fick gratis in their own houfes with every aflitance in food and medicine, and none thall be taken to the houfe of health excepting thole whom it hall be importible to allitit at home.

I have hitherto only direced the employment of about two hundred thoufand millions. There remain ftill near four millions of millions, the appro. priation of which 1 leave to the difcretion of my executors. I with them to purchafe and pull down all fuch houfes as inconimode the public way in all towns; to multiply fquares, quays, fountains, gardens, \&xc. in order to give falubrity to the air of towns; to empty ponds; to clear heaths; to deepen the beds of rivers fo as to rendet them navigable, and to unite them by mieans of canals; - in a word, I wifh them to co-operate in every polfible method with nacure, which feems to have defigned France * to be the mott dolightful country under heaven.

$$
\text { U } 2
$$

I hope

* France, undoubtedly, poffeffes fome of the beift na. tural advantages, and is a great kingdom. But it wants the firit of all advantages. It wants a fiee conltiturion of government. It wants civil and religious liberty. BS1TAIN enjoys thefe blefings; and this, though lefs than a fiur:b of FRANCE in extent and population, gives it a rat preeminence. in tay thefe blefings be foon recovered by one at

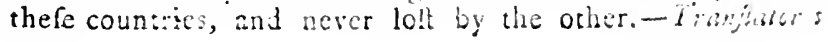
note. 


\section{[ 14.8 ]}

I hope that all good citizens will affitt my executors in the choice of fuch ufeful eftablinments as thall yet remain to be formed. I call upon them to publith the ideas with which patriotic zeal may infpire them, fince now they are encotraged by the confoling certainty that funds for executing them cannot be wanting.

I name tor executors my deareft and beft friends M. M. . . . . . . - [Here the teftator names fix executors, who do not think proper at prefent to reveal themfelves, and then goes on as follows].

$I$ beg of them to meet as often as the affairs of my executorhip thall require. In cafe of an equal divifion of opinions, the oldeft hall have the cafting vote. When one of them dies, I defire the furvivors to fill the vacancy, as foon as may be, with the moft honeft, zealous, and difinterefted citizen of their acquaintance, and to proceed in this manner for ever. I hope that during the firft years of their executorthip, when the operations of the fund will be eafy, they will tranfact in this bufinefs out of regard to me and to the public. I forefee that, in procefs of time, the fums to be laid out will become to immenfely great, as to render neceffary voyages and other confiderable expences, which will be productive of no profit. For this reafon I have left 125,000 livres of the fecond fum unappropriated; of the third 7I1,000; and of the fourth thirty-two millions. Thefe fums $I$ requeft them to accept as a compenfation for their expences and trouble. I charge them always, as far as they can, without hazarding the fecurity of the fund, to prefer thofe ways of laying out the accumulating fums which fhall be moft ferviceable to individuals and the public.

If a reduction in the rate of intereft, or any unforefeen lofres, hould injure the fund, fo as to re- 


\section{[ 149 ]}

tard its increafe, the execution of my defires need only be poftponed in proportion to the interruption that hall happen.

May the fuccefs of thefe eftablinments caufe one day a few tears to be fhed on my grave. Buc above all, may the example of an obfcure individual * kindle the emulation of patriots, princes, and public bodies; and engage them to give attention to this new but powerful and intallible means of ferving pofterity, and concributing to the future improvement and happines of the world.

* Durirg the printing of this Will, the Gazette de Frame announced a legacy of the fame kind, which will prove to our readers that thofe ideas may fometimes be realized. "We read in fome or our papers a very fingular fact. Judge "Normand, of Norwich, who died 1724 , male a will, in

" which he bequeathed toool. fterling towards building in 60

" years, from that time, a charity fchool, to the founding

" of which the principal, and its accumulating intereft,

" during this period, fhould be appropriated. His further

" difpofitions fix the number of fcholars to 120 , regulates

" their meals for every day in the week, each to have for

" dinner on Sunday a pound of roaft bcef, and in the even-

" ing ten ounces of plum-pudding. He invelts the ma-

" nagement of this íchool in the Bihop, the Chancellor,

" the Dean, the four members for the city and county, and

" eight clergymen. The period determined upon for tha

" execution of this Will expired in the month of May, and

"the accumulated fum amounts to 74,000l. Aterling."

Gazette de France, Friday, Aug. 13, 1784. No. 6:. 


\section{$\left[\begin{array}{ll}150 & \end{array}\right]$}

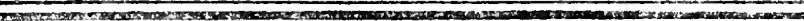

T A B L L E S .

No. I. **

Table of the Prodice of a Sum of 100 Livres, witb its accumulating Interef, during 100 Years, at 5 per Cent.

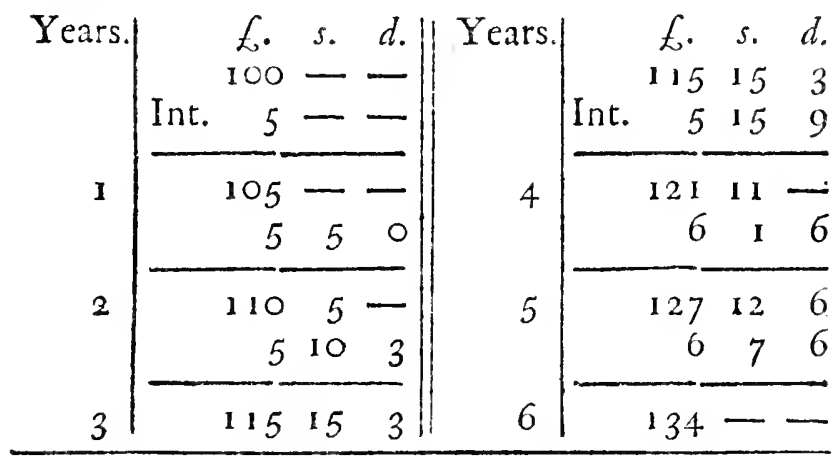

* Rule for an eafy Converfon of Livers into Pounds Sterling.

Strike off from the number of livres the two figures on the right hand, and muitiply by 4 the remaining figures, 'The product increafed by a tertb of itfelf will give nearly the number of pounds anfwering to the rumber of livres.

Thus. 100, noo livres are equal nearly to 4000 multiplied by ${ }$, and the product $(4000)$ increafed by 400 . That is, they are equal to $4400 \%$.

In like manner, :, $; 25,708$ livres are equal to $1, ;, 25 \%$ multiplied by 4 , and the product $(69,028)$ increated by 6goz. That is, they are equal to $75,9301,-2$ "whatar": note. 


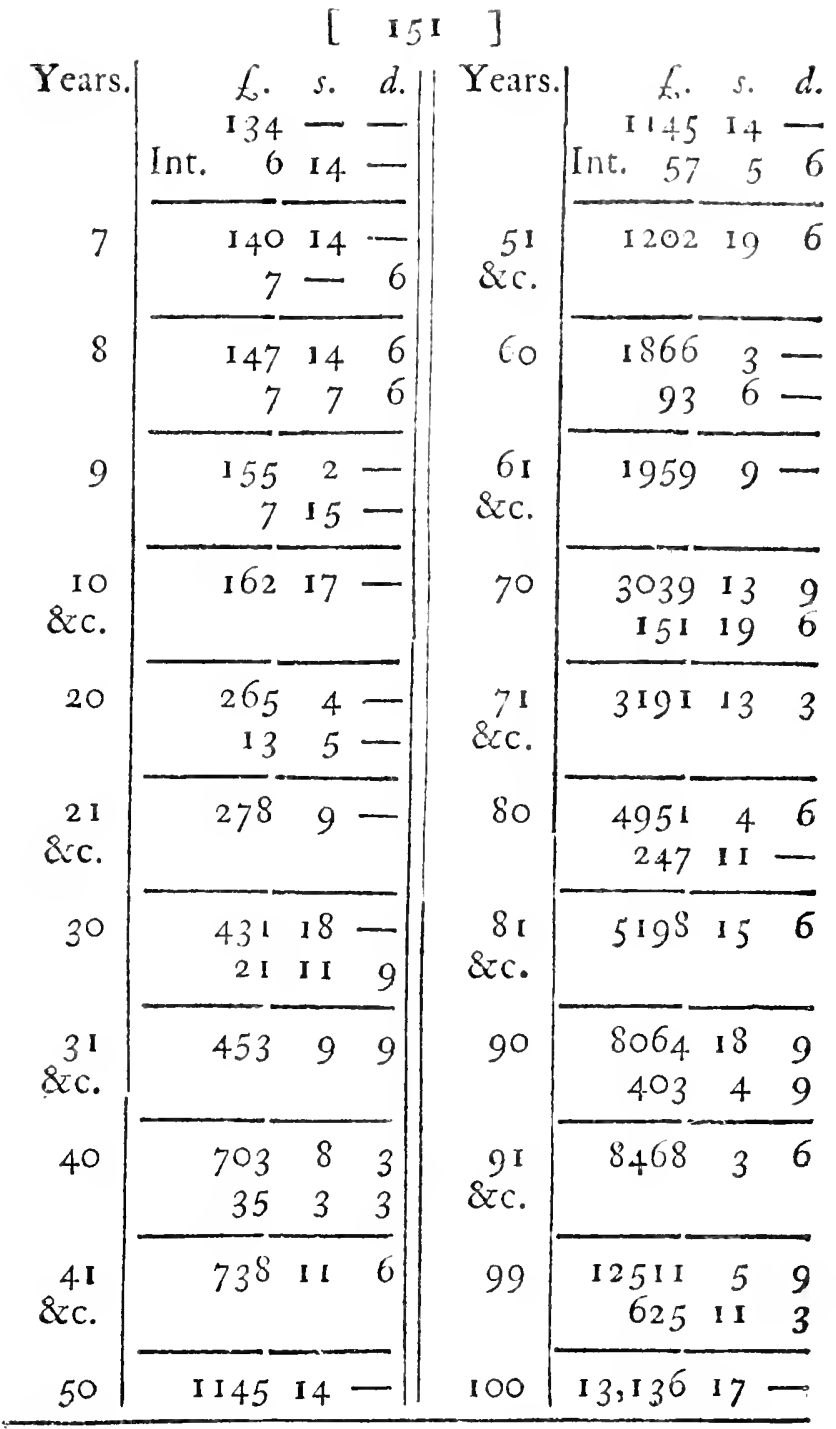

O B S E R V A T I O N S.

We found among the papers of the late $M$. Ricard a great number of very curious tables, but they 


\section{[ 152$]$}

they have not been inferted here becaufe they had no direct relation to the object of his Will. He had computed the produce of a fun of 100 livres, with the accumulated intereft of 200 years, ac. cording to the different rates of intereft; and the refults varied much more than could be believed from the proportion of thofe different rates.

Intereft at 4 percont.gives

at 5 per cent. -

507

at 6 percont. -

at 10 per cent.

131 times the ori-

$339\}$ ginal fum.

From hence it follows, that if the operations are well nanaged, and the money laid out to advantage, even by finking the principal, (as is done in the fund for the 30 girls of Geneva) and converting afterwards the annual produce into capitals, the executors might confiderably accelerate the accomplifhment of the benevolent difpolitions of the teftator.

By laying out the money every three months, as is the cuntom in fome commercial places, the operations might alfo be accelerated, although but in a fmall degree.

REMARK, by the Translator.

Thefe obfervations fhew that $M$. Ricard was himfelf poffefied in a high degree of that knowledge of arithmetic which he has required in the comptrollers-general (p. I39) as a condition of the redemotion of the debts of France. In the latt paragraph, however, there is an incurrectnels which thews that he had not atiended fufficiently to one circumfance in the improvement of money by compound intereft. This will appear from the following calculations. 


\section{[ 153 ]}

One hundred livres will amount, if improved at 5 per cent. intereft,

$$
\begin{gathered}
\text { Paid yearly. } \\
\text { Livres. }
\end{gathered} \quad \begin{gathered}
\text { Half-yearly. } \\
\text { Livres. }
\end{gathered}
$$

In 100 years to 131,501
In 500 years to $3^{\prime \prime}, 932,400^{\prime}, 000,000-5^{\prime \prime}, 296,139,560$

$$
139,560
$$

Paid quarterly.

In 100 years to 143,890 livres.

In 500 years to 6", $166,000,000,000$ livres.

By directing, therefore, that the laft hundred livies flould be improved at 5 per cent. quarterly intereft, M. Ricard might have gained an additional fum equal to $2^{\prime \prime}, 234,000^{\prime}, 000,000$ livres; that is, nearly equal to a bundred thoufand millions fterling, which is a fum more than fufficient to encompafs the earth with a belt of guineas all clofe and five feet broad.

\section{No. II.}

TABLE of the Produce of each Sum of 100 Livres, bequeatbed by the Tefator, from one bundred to five bundred Years.

It has been proved by the preceding table, that a fum of 100 livres, with the intereit accumulating at 5 per cent. for 100 years, will produce 13,136 liv. 17 fous. By multiplying this fum by itfelf four times fucceffively, it will appear that the following fums are the produce of each 100 livres at the end of each century.

Liv. Sous der.

$\mathbf{1}^{\text {noo. }}$ Produce of 100 livres, with the accumulated intereft during 100 years

$2^{\circ}$. Produce of 100 livres, with the intereft, during 200 years,

$3^{\circ}$. Produce of 100 livres in 300 years

$4^{\circ}$. Produce of 100 livres in 400 years

$5^{\circ}$. Produce of 100 livres in

$$
\begin{aligned}
& +13,13617- \\
& \text { - } 1,725,76856 \\
& 226,711,589126 \\
& 29,782,761,46113- \\
& \mathrm{X}^{3,912,516,739,074^{15}} \mathrm{No.1II}^{3}
\end{aligned}
$$




\section{$\left[\begin{array}{lll}154 & i\end{array}\right.$}

No. III.

TABiE of the Difpofition of the firft Sum, amounting io 13,136 livies it fous.

Livires fous den.

A prize of

Three others of 600 livres each - - 1,800 - An edition of the Prize Difcourfe, extracts

from the thrce others, with 50,000 copies $7,33617-$

Total $13,1 3 6 \longdiv { 1 7 - }$

\section{No. N.}

TABLE of the Difpofition of the fecond Sum, amounting to $1,725,-68$ livires 5 fous 6 dent.

Livres fous der.

A fund for 80 prizes of 100 livres each, $1,600,000 \ldots$ Referved towards defraying the expencus

of the executors.

$$
\text { Total } \frac{125,76856}{1,725,768} \frac{56}{5,6}
$$

\section{No. V.}

TABE of the Difolition of the third Sum, amounting to 220,7 i 1,589 liv. 12 jous 6 den.

Five hundred patriotic banks for lend-

$$
\text { Lizres fous dero. }
$$

ing money without intereft - 196,000,000 - -

Building iz mufeums at ;00,000 liv.

each - $6,000,000$

Fund for an annual income of $30,000,000-$ 100,000 lives for each mufe-
um

Referved towards defraying the expences

of the cxecutors

Total $\frac{711,589126}{226,715,589126}$

Fuing the three years enpleyet in building

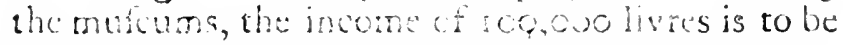

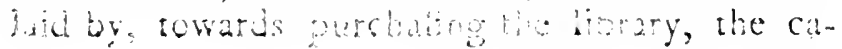
biners, 


\section{[ 155$]$}

binets, the carriages, the horfes, and ail the furn:ture of the mufeum. Afterwards it is to be $\mathrm{cm}$ ployed as follows.

Table-expences for the to members of the inufe Livres. um, the fix fecretarics, the derigner, the engraver, and all the domeflics, coichmen, cooks, $\}$ 50,000

Salaries of the fecretaries, defigner, engraver, ? and wages of the dometties,

Expences of the fable and carriagcs, _ $\quad 10,000$

The library and cabinets, - - 10,000

P.epairs of the bui!ding and furniture, - 8,000

Printing and unforcieen expences, - 10,000

Total 100,003

\section{No. VI.}

TABLE of the Diffofition of the ith Sum, anounting to $29,7 \$ 2,761,461$ liv. 13 jous.

'Fowards building 100 towns, containing each of them 150,000 fouls.

In order that thefe towns may be wholefome and convenient, it will be proper to confeciate to each of them a very large circular piece of ground, containing 6000 acres; which being ellimated at the highert, may be valued at 1000 livres each acre. By judging from the towns which now exift, there will not be required more than from 4, to 5000 houfes for 150,000 inhabitants; but it is not conducive to the health of mankind, to be fo crowded together. I fuppofe then that each of thefe towns may contain 7500 houfes*, which, one with the other, will colt 35000 livres in building. Each town will coit

Six thousand acres of ground at 1000 livres per acre 7,500 houfes, at 35,000 lives each houfe $262,500,000-$ Public buildings, town houles, bridges, churches, \&-c.

Liveres. fouts.

$$
6,000,000-
$$$$
\text { 29,000,000- }
$$

Total 297,500,000-

- It would hare been much better if M. Ricard had allowed a houfe for every family, which would have made the number of houles about 30000 . 


\section{[ 156$]$}

The preceding fum multiplied into 100 ,

Licures. fous.

Refresed toward's defraying the ex- $29,750,000,000-$ pences of the executors,

$$
\text { Total, } \frac{32,761,46113}{29,782,-61,46113}
$$

\section{No. VII.}

TABLE of the Difpofition of the 5 th Sum, amomnting to $3,912,516,739,074$ liv. I 5 jous 3 den.

The national debt of France, - 6 thoufand millions.

A fund towards dividing arnually 15 hundred thoufand livres among the pacific powers of Europe,

A fimilar diftribution among all the powers of the world, - 100 Abolition of lotteries, - 1 Extinction of ufelefs oflices, Supprelfion of venality in oftces of of importance,

A domaine to be ofrered to his Majefty,

A fund to be employed in annuities and penfions,

An addition to the fettled fipends of the clergy,

Ailowance to chiliken under three years of age, - - - ?

A foundation for 500 , coofmall freebolds with commodious cottages, 4 Enfranchifement of vafrals, $\quad-\quad z$

Foundations for houfes of education for the people, - $\quad-6$

Houfes of induftry, - 20 Afylums for penitent young women, I Hofpitals of Angels, - 2 Statues, bufts, and public honours, Houfes of health, - 10

Total of appropriated fums, 203 Remain unappropriated, $3,709,516,739,074153$ Total, $3,912,516,739,074153$ FI I I S . 

